\title{
Review
}

\section{The Tat-dependent protein translocation pathway}

\author{
Bo Hou and Thomas Brüser* \\ Institute of Microbiology, Leibniz University Hannover, \\ Schneiderberg 50, D-30167 Hannover, Germany \\ * Corresponding author \\ e-mail: brueser@ifmb.uni-hannover.de
}

\begin{abstract}
The twin-arginine translocation (Tat) pathway is found in bacteria, archaea, and plant chloroplasts, where it is dedicated to the transmembrane transport of fully folded proteins. These proteins contain $\mathrm{N}$-terminal signal peptides with a specific Tat-system binding motif that is recognized by the transport machinery. In contrast to other protein transport systems, the Tat system consists of multiple copies of only two or three usually small $(\sim 8-30 \mathrm{kDa})$ membrane proteins that oligomerize to two large complexes that transiently interact during translocation. Only one of these complexes includes a polytopic membrane protein, TatC. The other complex consists of TatA. Tat systems of plants, proteobacteria, and several other phyla contain a third component, TatB. TatB is evolutionarily and structurally related to TatA and usually forms tight complexes with TatC. Minimal two-component Tat systems lacking TatB are found in many bacterial and archaeal phyla. They consist of a 'bifunctional' TatA that also covers TatB functionalities, and a TatC. Recent insights into the structure and interactions of the Tat proteins have various important implications.
\end{abstract}

Keywords: protein folding; protein transport; redox protein biogenesis; twin-arginine translocation.

\section{Introduction: the origins of Tat research}

In many cases, proteins are synthesized in a place that is separated from their functional destination by a biological membrane. This subset of proteins must be transported across or into the membrane to reach their dedicated subcellular localization. Most of these proteins are initially synthesized as a larger precursor with an $\mathrm{N}$-terminal extension that is the so-called signal peptide (1). The signal peptide directs these proteins to specific membrane integral protein transport machineries - the so-called translocons, which can carry out this transport without compromising the permeability barrier of the membrane. Usually, most of the transported proteins or membrane proteins are targeted to the ubiquitous general secretion $(\mathrm{Sec})$ translocon, which is found in the endoplasmic reticulum membrane of eukaryotes, the cytoplasmic membrane of all prokaryotes, and in the thylakoid membrane of plant chloroplasts (2). Sec-dependently transported proteins are not allowed to fold before translocation. Folding is avoided in these cases either by a co-translational translocation mechanism or by chaperones and targeting factors that interact with precursor proteins in the cytoplasm, and protein domains of Sec substrates can be released either laterally into the lipid bilayer or to the trans side of the membrane, where they fold into their functional conformation (3).

Since the middle 1980s, the first implication of the existence of a parallel transport pathway dedicated to the transport of folded proteins in prokaryotes has arisen from the studies on a hydrogenase of the anaerobic sulfate-reducing bacterium Desulfovibrio vulgaris. This hydrogenase consists of two transported subunits that function as a heterodimer in the periplasm, but the sequencing of the genes in 1986 showed that only the smaller one of the two subunits contained a signal sequence (4). These authors considered already a novel transport mode but favored the existence of an internal signal peptide and could not imagine a cotransport of two proteins: 'Alternatively, the hydrogenase may be posttranslationally translated across the membrane with the small subunit acting as a carrier for the large subunit. In the absence of any experimental precedent for one subunit acting as a carrier for a second subunit for posttranslational translocation, this possibility is ... improbable'. Two years later, it was recognized that the improbable was likely: translocation of the hydrogenase required both subunits (5), suggesting that the large subunit was indeed transported piggyback via association with the signal-containing small subunit, which later turned out to be a general characteristic of hydrogenase transport (6). Thus, both subunits apparently had to fold to form a protein complex before translocation, which was incompatible with the Sec pathway for export of periplasmic proteins. Three years later, evidence showed that two conserved arginine residues in the signal peptide of the small hydrogenase subunit were important for transport of a reporter protein fusion (7). Strong evidences for the existence of a Sec-independent protein transport pathway also came from in vitro studies on protein transport in the thylakoid membrane of plant chloroplasts. A subset of proteins were reported to be imported into the thylakoid membrane in the absence of ATP or any other soluble factors that are essential for the Sec pathway, but the import apparently was facilitated solely by a $\mathrm{pH}$ gradient $(\Delta \mathrm{pH})$ across the thylakoid membrane (8-10). Remarkably, almost all of those proteins carried a signal peptide bearing a unique twin-arginine motif 
(11). In 1996, it was proposed that homologous protein transport systems are employed to transport complex redox-cofactor-containing and thus folded precursor proteins across the bacterial cytoplasmic membrane and many proteins across the thylakoid membrane of plant chloroplasts (12). The idea that both systems were likely to be homologous was based on the recognition that the signal peptides for both systems contained the conserved RR-motif amino acid pattern. Also the plant thylakoid pathway appeared to be adapted to the transport of folded proteins since it was found to be inhibited when folding was affected (13). The first component of this novel translocation system, Hcf106, was discovered soon thereafter in the thylakoid system and, indeed, genes with homology to hcflo6 were found in prokaryotes (14). Only a little time later, the bacterial system has been independently identified by a functional screen in Escherichia coli (15), and also a directed inactivation of the genes homologous to $h c f 106$ of the plant system demonstrated the existence of this novel transport system in bacteria (16). Soon after naming this new pathway Mtt (for membrane targeting and translocation) (15), the name Tat (for twin-arginine translocation) was proposed to emphasize the twin-arginine motif that is found in the substrates of this pathway (16). Since then, research on this pathway has expanded rapidly, resulting in marked progress on the structural and functional characterization of the Tat translocon and functional models of the translocation mechanism.

\section{Tat signal peptides contain the Tat pathway determinants}

Tat signal peptides are present at the N-terminus of Tatdependently translocated precursor proteins. Tat signal peptides have been found to be unfolded in solution in the presence of a folded mature domain (17). On the basis of the known Tat signal peptides of E. coli, they have an average length of about 33 amino acid residues (18); however, length varies considerably. A survey of representative signal peptides from bacterial, archaeal, and plant sources, including signal peptides of often-studied Tat substrates, is given in Figure 1. Tat signal peptides possess a common tripartite structure, including a polar N-terminal (n-) region, a moderately hydrophobic (h-) region, and a hydrophilic short $\mathrm{C}$ terminal (c-) region, that usually determines the position of a signal peptide cleavage site (Figure 1). Tat signal peptides resemble Sec signal peptides in their overall structure, and when fused to unfolded Sec substrates the majority of the analyzed Tat signal peptides indeed can target proteins to the Sec pathway (18). This suggests that the Tat-exclusive targeting often is rather a result of the folding of the mature domain than a consequence of signal peptide characteristics. The most remarkable feature of the Tat signal peptides is the conserved amino acid motif S/T-R-R-X-F-L-K that includes the almost invariant arginines that are eponymous for the pathway (19). On the basis of the knowledge of more signal sequences, this motif was also described as a simpler pattern, $\mathrm{Z}^{-1}-\mathrm{R}^{0}-\mathrm{R}^{+1}-\mathrm{x}^{+2}-\Phi^{+3}-\Phi^{+4}$, where $\mathrm{Z}$ stands for any polar res- idue and $\Phi$ stands for hydrophobic residues (Figure 1) (20). The numbering of the positions relative to the first of the twin-arginines has been introduced by Rose et al. (21). This pattern could also fit to almost all thylakoid Tat signal peptides (22). In exceptional cases, plant Tat substrates possess hydrophobic residues at the -1 position and small hydroxylgroup-containing side chains at the +3 position (Figure 1 ). Thylakoid Tat signal peptides can be functionally exchanged by bacterial Tat signal peptides (23-25). The consensus motif is always located at the interface of the n- and the hregion, and its conservation is useful to identify Tat signal peptides in proteomes with programs such as TATFIND or TatP $(21,26,27)$ (Figure 1). The E. coli genome, for example, was predicted to encode 29 proteins carrying Tat signal peptides, and 27 of these proteins were experimentally proven to be Tat pathway substrates (18).

The second arginine of the twin-arginines is more important than the first arginine (28-31). To date, all known natural Tat precursor proteins possess an arginine at the second position, but a few precursors are known that possess a lysine at the first position $(32,33)$ (Figure 1). Another exception might be the pre-propenicillin amidase of E. coli, which carries an $\mathrm{R}-\mathrm{N}-\mathrm{R}$ motif (34). A RR $>\mathrm{KK}$ exchange abolishes the transport of natural Tat substrates $(28,35,36)$. However, recombinantly produced colicin $\mathrm{V}$ could be exported via the E. coli Tat pathway even when fused to a Tat signal peptide containing a KK-motif (30). Beside the arginines, the hydrophobic residues located at the positions +3 and +4 relative to the first position of the twin-arginines are also highly important for the function of the Tat signal peptides $(35,37$, 38).

The n-regions of the Tat signal peptides are apparently less important for functionality, although the overall hydrophilic nature of this region seems to be relevant for Tat specificity (39). In very long signal peptides, such as GFOR of Zymomonas mobilis, the n-region can be longer than 30 residues, which shows that RR-motifs can be recognized quite far away from the N-terminus (Figure 1). The h-region is a stretch of 13-20 uncharged residues with in average lower hydrophobicity but larger size than h-regions of Sec substrates (21). The hydrophobicity of the h-region appears to be highly important for Tat transport: an artificial increase of the hydrophobicity of a Tat signal peptide enabled it to be recognized by the Sec pathway (40). In agreement with this observation, a transfer of a RR-motif into a Sec signal peptide was found to be insufficient for Tat targeting (41).

The c-region of Tat signal peptides often, but not always, contains positively charged residues. This is rather exceptional in Sec signal peptides, and such positively charged residues can function as 'Sec avoidance signal' at least in some cases $(42,43)$. Signal peptides usually have a consensus A-X-A motif that serves as the cleavage site for signal peptidase (44). Some Tat signal peptides are known that are not cleaved off after transport and thus serve as a transmembrane domain (TMD) (31-33). Polar or charged residues are often found near the cleavage site, while increasing the hydrophobicity around the cleavage site could impair the processing (45). The border between h- and c-regions is not 


\section{n-region h-region c-region}

$\operatorname{ZRRx} \Phi \Phi$

Bacterial Tat signal peptides

E.coli DmsA

E.coli TorA

E.coli NapA

E.coli HyaA

E.coli SufI

E.coli CueO

E.coli YcdB

A.vin. HiPIP

S.ent. HybO

S.ent. TtrB

P.den. Rieske

Z.mob. GFOR

D.gigas HydA

B. sub. PhoD

B.sub. YwbN

St.liv. $\quad \mathrm{X} \ln B$

Archaeal Tat signal peptides

Ha.his. $\quad \mathrm{mmyH}$

Hf.vol. $\quad B 0232$

Hb.NRC1 Hly

Nc. AH36 Amy

Plant Tat signal peptides

Ho.vulg. PSI-N

Ar.thal. PSII-T

Ar.thal. Hcf136

Sp.ole. OEC16

Sp.ole. OEC23

Sp.ole. Rieske

\section{MKTKIPDAVLAAEVSRRGLVKTTAIGGLAMASSALTLPFSRIAHA MNNNDLFQASRRRFLAQLGGLTVAGMLGPSLLTPRRATA MKLSRRSFMKANAVAAAAAAGLSVPGVARA \\ MNNEETFYQAMRRQGVTRRSFLKYCSLAATSLGLGAGMAPKIAWA \\ MSLSRRQFIQASGIALCAGAVPLKASA MQRRDFLKYSVALGVASALPLWSRAVFA}

MQYKDENGVNEPSRRRLLKVIGALALAGSCPVAHA MSDKPISKSRRDAVKVMLGTAAAIPMINLVGFGTARA

MTGDNTLITSHGINRRDFMKLCAALAATMGLSSKAAA MWTGVNMDSSKRQFLQQLGVLTAGASLVPLAEA

MSHADEHAGDHGATRRDFLYYATAGAGTVAAGAAAWTLVNQMNP (not cleaved)

MTNKISSSDNLSNAVSATDDNASRTPNLTRRALVGGGVGLAAAGALASGLQA

MKCYIGRGKDQVEERLERRGMSRRDFMKFCTAVAVAMGMPAFAPKMAEA

MAYDSRFDEWVQKLKEESFQNNTFDRRKFIQGAGKIAGLSLGLTIAQSVGAFEVNA

MSDEQKKPEQIHRRDILKWGAMAGAAVAIGASGLGGLA

MNLLVQPRRRRRGPVTLLVRSAWAVALAALAALMLPGTAQA

\author{
MNRPRITGSKQASRRTVLKGIGVLGAAVFGTAASVGSSAA \\ MSERNSSRQHSRRKYLAALGAAGVAAVGSTGVIA \\ MADNTNVTRRSFLTATGAAAGSVALVGVSA \\ MRRNHSHTSDSAGIDRRTVLRSSAAAGALALTGVTIGSTSAAA
}

...AKRVQVAPAKDRRSALLGLAAVFAATAASAGSARA
...LEVKEQSSTTMRRDLMFTAAAAAVCSLAKVAMA
...PSSSSSSLSFSRRELLYQSAVSLSLSSIVGPARA
...AQQVSAEAETSRRAMLGFVAAGLASGSFVKAVLA
...NEANVLBSGVSRRLALTVLIGAAAVGSKVSPADA
...SIPADNVPDMQKRETLNLLLLGALSLPTGYMLLPYASFFVP (not cleaved)

Figure 1 Tat signal peptides.

A schematic structure of a tripartite twin-arginine signal peptide is shown at the top of the figure. The n-region (light blue), h-region (yellow), and c-region (purple) are shown, with the consensus ZRRxФФ motif located at the interface of the $\mathrm{n}$ - and h-region. Amino acid sequences of a selection of representative or often-studied Tat signal peptides from various organisms are listed, including E. coli (Escherichia coli) DmsA (dimethyl sulfoxide reductase), TorA (trimethylamine N-oxide reductase), NapA (periplasmic nitrate reductase), HyaA (hydrogenase 1, small subunit), SufI/FtsP (stabilization of divisome) (186), CueO (multicopper oxidase; copper stress response), YcdB/EfeB (periplasmic deferrochelatase) (52), A. vin. (Allochromatium vinosum) HiPIP (high potential iron-sulfur protein), S. ent. (Salmonella enterica) HybO (hydrogenase 2, small subunit), TtrB (tetrathionate reductase subunit B), P. den. (Paracoccus denitrificans) Rieske [Rieske (2Fe-2S) domain subunit of complex III], Z. mob. (Zymomonas mobilis) GFOR (glucose-fructose oxidoreductase), D. gigas (Desulfovibrio gigas) HydA [periplasmic (Fe) hydrogenase large subunit], B. sub. (Bacillus subtilis) PhoD (alkaline phosphatase D), YwbN (YcdB/EfeB homologue of B. subtilis), St. liv. (Streptomyces lividans) XlnB (xylanase B), Ha. his.(Haloarcula hispanica) AmyH (Amylase), Hf. vol. (Haloferax volcanii) Protein B0232, Hb. NRC1 (Halobacterium NRC1) Hly (Halolysin), Nc. AH36 (Natronococcus AH36) Amy (Amylase), Ho. vulg. (Hordeum vulgare) PSI-N (photosystem-I subunit N), Ar. thal. (Arabidopsis thaliana) PSII-T (photosystem-II subunit T), Hcf136 (photosystem II stability/assembly factor HCF136), Sp. ole. (Spinacea oleracea) OEC16 (16-kDa protein of oxygen evolving system of the photosystem II), OEC23 (23-kDa protein of oxygen evolving system of the photosystem II), and Rieske (Rieske FeS subunit of $b_{6} f$-complex). The twin-arginine positions are in blue/bold, the hydrophobic positions in red/bold, the prolines in the second half of the h-region in green/ bold, and the positive charges close to the cleavage site in blue/bold. The uncharged stretch of a minimum of 13 residues that follows the last charge of the n-region is underlined up to four residues before the cleavage site. Some exceptional residues in positions of plant RRmotifs are indicated in purple/bold.

well defined, especially because the h-regions of Tat substrates often contain polar uncharged residues. It is interesting that many Tat signal peptides contain proline residues in this region, which might help disrupt a continuous helical secondary structure during transport or facilitate signal peptide cleavage (Figure 1).

\section{The Tat pathway is adapted to the translocation of folded globular proteins or protein domains}

In E. coli, 27 out of 452 predicted cell envelope proteins are shown to be Tat-dependently translocated $(18,46)$, and most 
contain redox cofactors, including very often FeS clusters, $\mathrm{NiFe}$ centers, molybdenum- or tungstate-containing cofactors, but also NADP, copper centers, cobalt-corrin complexes, or heme, among others $(19,47-49)$. These redox proteins often play important roles in respiratory and photosynthetic pathways, and some have other specific functions, for example, in processes such as iron acquisition, copper resistance, or cell division (50-54). In the case of the redox proteins, Tat-dependent transport of folded proteins allows for the use of cytoplasmic cofactor assembly pathways for extracytoplasmic proteins. In Streptomyces coelicolor, at least 145 proteins are predicted to be Tat-dependently translocated, which is an estimated proportion of about $16 \%$ of the exported proteins (55). Also $\alpha$-proteobacteria from the genera Mesorhizobium or Sinorhizobium have a large number of Tat substrates (27). While these organisms have large genomes, it is interesting is that Caulobacter crescentus is among the bacteria with more than 80 predicted Tat substrates, although this organism encodes fewer proteins in its genome than $E$. coli (27). Also halophilic archaea, such as Halobacterium NRC1, encode a large number of Tat substrates, and they have in common with Caulobacter that the majority of these Tat substrates seem to have no cofactors $(21,27)$. In the case of the halophilic archaea, it is likely that the high intracellular potassium salt concentration influences protein folding that could result in the need to transport more proteins by the Tat system $(21,56)$. Interestingly, prokaryotes that do not contain Tat systems exist, and these have an obligate fermentative or parasitic metabolism that does not require the transport of cofactor-containing proteins (27), which underlines the key function of redox protein transport for the Tat system.

The maximum size of translocated folded Tat substrates may be near $150 \mathrm{kDa}$, as the largest Tat substrate of E. coli, a formate dehydrogenase, is transported as a $142-\mathrm{kDa}$ dimer, but the size limit for globular proteins has not been analyzed systematically. The transport of folded proteins has been clearly demonstrated in E. coli with green fluorescent protein (GFP) fused to a Tat signal peptide. GFP cannot fold to a fluorescent protein in the periplasm (57), but Tat-dependently translocated GFP shows periplasmic fluorescence, indicating folding in the cytoplasm before translocation $(58,59)$. The adaptation to the transport of folded proteins is best reflected by the fact that the Tat transport apparatus usually is unable to transport partially folded proteins, such as proteins that have to form disulfide bridges or that have to assemble cofactors for complete folding (60-62). Also the thylakoidal Tat system can transport folded proteins and most likely serves this purpose in contrast to the Sec pathway that serves to transport unfolded proteins. The first evidence came from studies with an OE16 Tat substrate fused to bovine pancreatic trypsin inhibitor that indicated transport of the folded substrate, as the protein could be cross-linked to a proteaseresistant form before translocation (63). Another direct evidence came from the in vitro thylakoid import of dihydrofolate reductase (DHFR) that was fused to an authentic Tat precursor protein (64). DHFR binds to methotrexate (MTX) with very high affinity, resulting in a very tightly folded conformation that is resistant to even high concentra- tions of proteases. In this state, DHFR was rejected by the mitochondria import machinery or by the bacterial Sec apparatus that are only able to transport unfolded proteins (65). In contrast, binding of MTX did not block translocation of DHFR into the thylakoid lumen by the Tat pathway, and moreover, the binding ligand MTX was cotranslocated into the lumen (64). The tolerance of unfolded regions by the thylakoidal Tat system depends on the individual substrate, and it was shown that unfolded hydrophilic linker peptides are compatible with thylakoidal Tat transport (66).

It has been shown that recombinantly produced misfolded substrate proteins can reach the Tat translocon, which then fails to fully transport the proteins (67). A strong RR-dependent growth inhibition is induced by unfolded globular proteins that are targeted to the Tat system, indicating that the Tat machinery attempts to translocate such proteins, resulting in a destabilization of the cytoplasmic membrane (67). Interestingly, Tat signal peptide fusions of small (up to $25 \mathrm{kDa}$ ), natively unfolded hydrophilic protein domains were successfully transported in the presence of increased amounts of Tat systems, indicating that tight folding of globular proteins cannot be a strict requirement for the Tat mechanism (68). Globular domains fused to the C-terminus of such unfolded domains restricted the length of tolerated unfolded linker domains, which depended on the total volume of the linker and the fused globular protein (69). Two fused globular domains could be translocated in a way that allowed for the detection of the halfway transported intermediate (70). While the Tat system thus has a remarkable tolerance toward unfolded regions or connected globular domains, it could be shown that surface-exposed hydrophobic patches are incompatible with Tat transport (68). This indicates that larger globular Tat substrates cannot be translocated in unfolded states because of size limitations and the surface exposure of hydrophobic core regions. The cells must therefore ensure that proteins tightly fold before their interaction with the Tat machinery. This can be achieved by chaperones and proteases of the known cytoplasmic folding quality control systems (71).

The adaptation to the transport of folded globular proteins has been successfully used to achieve a 'biotechnological folding quality control' that allowed for a selection of more hydrophilic and thus more soluble protein surfaces (72-75). The Tat-based methods developed by the group of DeLisa have enormous relevance for biotechnological applications, especially for the development of pharmaceutically relevant proteins with improved characteristics.

Many polypeptides are transported as subunits of oligomeric proteins that contain a Tat signal peptide at a different subunit $(6,19)$. As already mentioned in the first section of this review, transport of these proteins is achieved by a 'hitchhiker' or 'piggyback' mechanism, which is quite common for Tat transport. Transport of the Tat signal-containing subunits before their association with the other subunits is inhibited, most likely by specific chaperones (see below), to avoid transport of premature proteins into the periplasm (76, 77).

Besides the possibilities to anchor Tat substrates to the membrane via unprocessed signal peptides or membrane- 
integral subunits of heterooligomeric proteins, several Tat substrates have been analyzed that are anchored via a Cterminal membrane anchor (78). This is very interesting as it shows that transport can be achieved in a way that permits the membrane insertion of a C-terminal hydrophobic extension. There is no Tat substrate known that has two translocated hydrophilic domains connected by two TMDs. This may suggest that the Tat system cannot bind two times at different positions to single Tat substrates to initiate transport of the following domain. Proteins that consist of distinct hydrophilic domains, such as two GFP in tandem, may be translocated with one transport initiation only (70).

\section{Tat signal peptide-binding chaperones are involved in folding, cofactor assembly, and signal peptide protection before translocation}

The folding of many Tat substrates inside the cytoplasm requires assistance of other proteins. Some bacterial Tatdependent redox proteins recruit specific chaperones for folding, cofactor integration, and oligomerization with partner proteins. These specific chaperones are often encoded in operons together with the Tat substrates. It appears that these specific chaperones are involved in the assembly of cofactors into their cognate Tat substrates, and they have been termed redox enzyme maturation proteins (REMPs) (79).

The well-characterized examples of REMPs of $E$. coli include TorD, which is involved in the cofactor assembly and folding of the TMAO reductase TorA (80-85), DmsD, which acts on the DMSO reductase catalytic subunit DmsA (86-91), and NapD, which is dedicated to the cytoplasmic activation of the periplasmic nitrate reductase NapA (92-94).

E. coli TorA and its membrane-integral electron delivery protein TorC, as well as the TorA-specific REMP TorD, are encoded in the torCAD operon (95). The TorA protein assembles a bis(molybdopterin guanine dinucleotide) molybdenum cofactor inside the cytoplasm. For a long time, TorD has been known to be bound to TorA and maintain it in a conformation suitable for cofactor integration $(81,84,96)$. TorD binds the signal peptide of TorA with high specificity and interacts most likely also with the mature domain (82, $83,85)$. The RR-motif itself is not essential for this interaction, as an $\mathrm{RR}>\mathrm{KK}$ variant signal peptide is recognized by TorD with comparable affinity (85). The TorD chaperone has been shown to protect the signal peptide of TorA from degradation $(97,98)$. It is unclear whether TorD directly delivers TorA to the Tat machinery, but it unequivocally contributes to folding before translocation. There is good evidence that the availability of TorD or other signal peptide binding chaperones limit the transport of Tat substrates on a targeting level, as an overproduced TorA signal peptide or TorA signal peptide-GFP fusion selectively inhibited the translocation of the full-length TorA (99).

The E. coli DMSO reductase is a membrane-bound trimeric molybdoenzyme that consists of two periplasmic subunits, DmsA and DmsB, that are anchored to the membrane by a third subunit, DmsC, which is independently membrane inserted. Genes encoding all three proteins are grouped in the $d m s A B C$ operon $(100,101)$. DsmA, but not DsmB, possesses a Tat signal peptide, and DmsB is therefore cotranslocated together with DmsA. The REMP DmsD is not encoded in the $d m s A B C$ operon but is required for DmsA biogenesis before transport (90). It may also play a role for other molybdoenzymes of this family (19). DmsD binds specifically to the Tat signal peptide of DmsA, and has only low affinity to other signal peptides such as that of TorA (88, 102). DmsD interacts with the DmsA signal peptide in a $1: 1$ ratio and requires an $\mathrm{N}$-terminal position of the signal peptide in the precursor (88). An exchange of the DmsA signal peptide by a TorA signal peptide resulted in marked decrease of DMSO reductase activity, most likely because efficient DmsD binding is required for the folding or cofactor assembly of DmsA (103). DmsD belongs to the TorD superfamily of proteins, which includes other REMPs such as YcdY and NarJ. NarJ is a REMP of the cytoplasmic protein NarG that has an N-terminus with rudimentary similarity to Tat signal peptides that could be altered to a Tat signal peptide by targeted mutagenesis $(104,105)$.

The E. coli NapD is a small cytoplasmic protein that is essential for activity of the periplasmic nitrate reductase NapA (93). NapD binds to the Tat signal of NapA tightly in vitro, and overproduction of NapD results in retardation of Tat-dependent export of NapA, suggesting that NapD plays a role to prevent premature export of NapA (94). The NapD structure revealed that this REMP belongs to a different protein family than the TorD-like REMPs (94).

Hydrogenases also have their specific REMPs. The E. coli hydrogenase I signal peptide-containing small subunit HyaA interacts with the chaperone HyaE. The chaperone HybE is specific for hydrogenase II. Interestingly, HybE binds not only the signal peptide of the small subunit HybB but also the full-length form of the large subunit HybC (76). The small subunit HoxK of the membrane-bound hydrogenase of Ralstonia eutropha has two chaperones that specifically bind its signal peptide, HoxO and HoxQ (77).

Not only specific REMPs but also general chaperones such as DnaK, SlyD, and GroEL interact with Tat substrates (91, 106, 107). General chaperones can assist in folding of Tat substrates and it has been shown that they can improve the yield of recombinantly produced Tat substrates (106). Interestingly, DnaK and SlyD were shown to bind to various Tat signal peptides $(91,107)$. The high-affinity binding of SlyD to various Tat signal peptides has been used to localize the chaperone active site in SlyD (108). In vitro data indicate that SlyD does not directly promote translocation (109). As the unfolded signal peptides of Tat substrates are highly susceptible to unspecific degradation and as only a subset of Tat substrate signal peptides can be protected by specific REMPs, general chaperones may serve such a protective role more generally. SlyD thus would act in the same way on Tat signal peptides as it does on the E-lysis protein of phage $\phi X 174:$ SlyD protects this protein from degradation, which is essential for membrane targeting of this protein and phageinduced cell lysis (110). Interestingly, SlyD has an additional function in the assembly of nickel into hydrogenases of E. coli (111-113). 

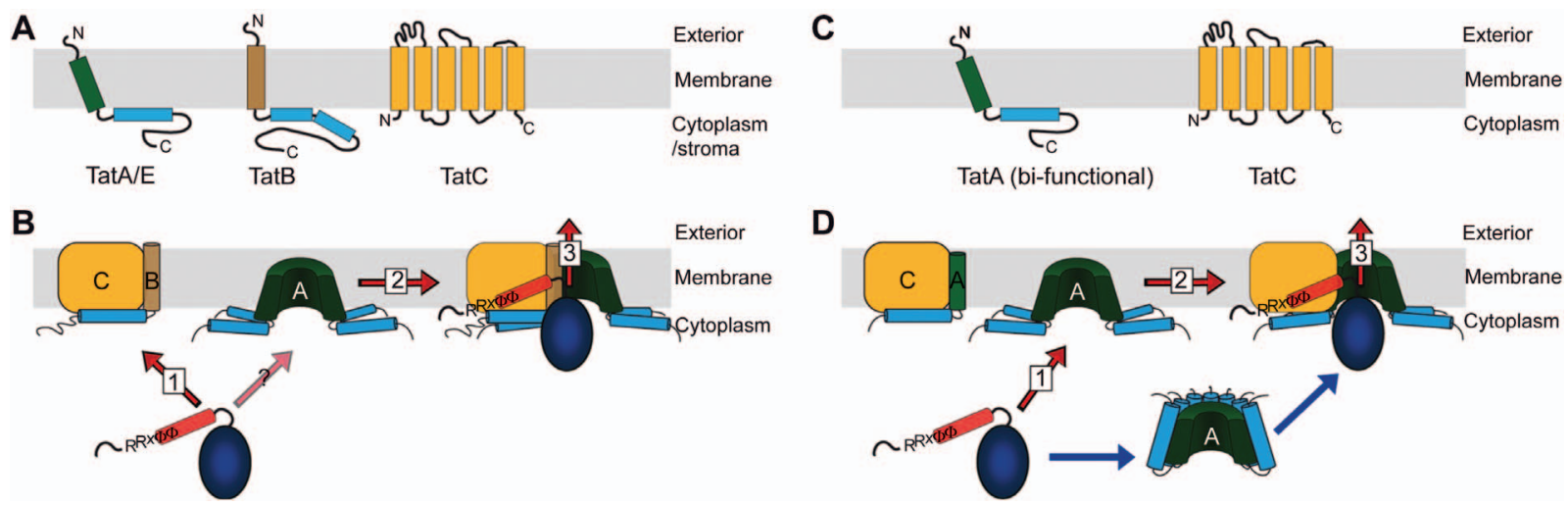

Figure 2 Components and models for the mechanism of the Tat translocon.

(A) Schematic structures of Tat translocon components of three-component TatABC systems. The TMDs of each protein are indicated by differently colored rectangles, while the amphipathic helixes are shown as blue rectangles. (B) Working model of the TatABC-dependent translocation in plants and proteobacteria. The mechanism can be dissected into at least three steps: 1) Tat signal peptides bearing the consensus ZRRxФФ motif target the precursor protein (possibly via an initial membrane interaction) to the TatBC complexes. The role of the TatA complexes is unclear. 2) Formation of the active TatABC translocon. 3) pmf-driven translocation of the mature domain. The mature domain remains folded during the whole process. (C) Tat translocon components of two-component TatAC systems. Colors are as in (A). (D) Working model for the TatAC system, involving a TatA-dependent targeting to TatC. Precursors may be recognized in the cytoplasm by TatA complexes that may shield their hydrophobic N-terminus by interactions with the amphipathic helix.

\section{The Tat translocon consists of the polytopic membrane protein TatC and one or two membrane-anchored TatAB family proteins}

The first Tat translocon component gene, hcf106, was identified in a maize mutant that exhibited a high chlorophyll fluorescence $(h c f)$ phenotype (14). In this mutant plant, biogenesis of chloroplasts was severely impaired while thylakoid membranes failed to import proteins via an, at that time novel, $\mathrm{pH}$ gradient $(\Delta \mathrm{pH})$-dependent pathway. Interestingly, the hcflo6 homologs in Enterobacteriaceae were usually located in an operon encoding four proteins that were termed TatA, TatB, TatC, and TatD. Studies with mutant strains have proven that TatA, TatB, and TatC are involved in Tat-dependent translocation, whereas TatD has no known function in this pathway $(15,16,114-116)$. TatA and TatB and their plant counterparts Tha4 and Hcf106 both belong to one protein family with similar overall structure (117). They are all membrane integral proteins with a single TMD, followed by a hinge region, an amphipathic helix, and a most likely unstructured C-terminal domain (Figure 2A) $(118,119)$. TatA proteins usually have a size between 50 (Magnetospirillum) and 102 (Amycolatopsis) amino acids, whereas TatB proteins are significantly longer in their C-terminal domain and vary between 113 (Azotobacter) and 220 (Yersinia) amino acids. Some TatA proteins have an N-terminal extension (e.g., Mycobacterium smegmatis or Providencia species) and it could be demonstrated in one case that such an extension was specifically processed by a rhomboid protease, which indicates a periplasmic localization of the $\mathrm{N}$-terminus (120). A second paralog of tatA is often found at a different locus than the $\operatorname{tat} A B C$ operon in bacterial genomes, and the gene is then usually termed tat $E$, at least in proteobacteria (16). In E. coli, deletion of either tatA or tatE does not completely abolish Tat transport, whereas the deletion of both genes completely blocks transport, indicating that one protein can complement the function of the other (16). Only in TatA, not in TatB, a single alanine substitution could be found that resulted in complete block of transport even with very sensitive transport assays, which is F39A, a residue close to the end of the amphipathic helix (121-124). A positive selection approach yielded TatA-inactivating exchanges that affected the helical nature or hydrophobicity of the N-terminus, the flexibility of the hinge region, or the sequence of the amphipathic region of TatA, indicating the importance of these regions for Tat transport (125). A cysteine scanning analysis suggested a special importance of the amphipathic helix of TatA, since 13 inactivating cysteine exchanges mapped in the amphipathic helix, and only two outside (Q8 in the TMD and G21 of the hinge) (122). The C-terminal parts of TatA and TatB are believed to be largely unstructured, and these regions are not essential for Tat transport (126).

TatC is the largest membrane protein of the Tat translocation machinery $(\sim 28 \mathrm{kDa})$, with six TMDs $(127-129)$. It contains important residues in its $\mathrm{N}$-terminal half that most likely are involved in substrate binding (130). The homolog of TatC in plants has been identified and named cpTatC (131). Genes encoding all three Tat proteins are found in proteobacteria as well as in many actinobacteria and cyanobacteria. However, the situation is quite different in other cases, such as in low-GC Gram-positive bacteria like Bacillus subtilis, or in archaea, in which bifunctional TatA-like proteins (that combine TatA and TatB functions) and TatC form together the so-called two-component Tat systems or minimal Tat systems (Figure 2C) $(132,133)$. The distinction of TatA from TatB cannot be easily made by sequence analysis. Many but not all Tat-system-containing low-GC Grampositive bacteria and archaea contain two or even three TatA-like proteins that can form translocons with distinct TatC proteins. In B. subtilis, it could be shown that the two 
TatAC systems function in parallel with a specific adaptation to certain substrates, which indicates that substrate-specific routes can exist in certain species (132). Heterologous Tat systems in E. coli showed only little evidence for substrate specificity if Tat systems of mesophilic organisms with similar membrane lipids were tested (134), and the substratespecific Tat systems of B. subtilis accepted E. coli Tat substrates $(135,136)$. Also haloarchaea may contain several Tat systems that function in parallel, and a cluster of two TatC-encoding genes has been identified that is essential for growth $(137,138)$. Of two TatA proteins, only one has been found to be essential, suggesting that the essential TatA cooperates with both TatC proteins (137). Interestingly, one of the TatC proteins of haloarchaea often is a fusion of two TatC proteins that are connected by two additional TMDs, resulting in a total of 14 TMDs $(137,138)$.

In Rhodobacter species, the tatABCF operon includes a fourth gene, $t a t F$, whose translational start overlaps with the stop codon of tatC, indicating a translational coupling (134). In other genera of $\alpha$-proteobacteria, the gene is associated with the Sec system. The gene product TatF belongs to the AAA family of proteins and has been proposed to be involved in protein transport (134).

\section{Tat translocon components form two complexes}

In three-component Tat systems such as found in E. coli or in thylakoid membranes, it is well established that TatB associates with TatC to form a stable TatBC complex that is able to bind substrate proteins $(67,139,140)$. Within this complex, multiple TatB and TatC protomers are present in a 1:1 ratio (141). Very recently, TatC has been shown to form a functional dimer with only one protomer being required for activity, indicating that TatBC complexes should have an even number of subunits (142). TatC binds directly to the RR-motif of the signal peptides that are deeply inserted into the TatBC complex (143-145). Thus, the TatBC complex has been proposed to function as a receptor of this pathway. Also TatA is found in the TatBC complex when all three components are recombinantly produced (141). However, it has been reported that TatBC complexes do not contain TatA at native expression levels (146). The E. coli TatBC complexes migrate at 440 and $580 \mathrm{kDa}$ in blue native PAGE analyses of digitonin-solubilized membranes $(67,139)$. The upper band has been found to contain bound Tat substrates that may thus cause a gel shift $(67,147)$. On the basis of electron microscopy data, TatBC complexes have been proposed to have heptameric symmetry (147). Bound Tat substrates could be visualized by electron microscopy as appendices of TatBC complexes (147). TatBC complexes are found at polar subcellular positions in E. coli and B. subtilis (148-150). This localization is in agreement with the RR-dependent targeting of Tat signal peptide linker-peptide-containing GFP fusions to the cell poles of E. coli (151).

TatA from E. coli forms multiple homooligomeric complexes with variable size from 50 to $>600 \mathrm{kDa}$, and the apparent complex size or thylakoidal TatA depends on the solubilization, indicating that detergents influence the size of TatA complexes in blue native PAGE analyses (67, 139, 140, $152,153)$. Solubilized recombinant $E$. coli TatA was reported to form ring-like structures that are covered on one side, which has been observed by electron microscopy (152); however, it is not clear whether these structures have a physiological function. When moderately overproduced, TatA has been shown to form large tubular structures in the bacterial cytoplasm that arrange to clusters that depend on the presence of TatC (151). The inner diameter of these hollow tubes is $7 \mathrm{~nm}$, which would fit to the estimated maximum diameter of Tat substrates. It has been speculated that TatA might form small tubes at native level. Also TatA of plants has been shown to form very large soluble complexes, and it could be shown that such soluble TatA can promote translocation (154). Significant populations of soluble TatA have also been reported from actinobacteria, firmicutes, and archaea, especially when the TatA protein was recombinantly produced (137, 155-157). At the native expression level, the majority of TatA is found in membrane fractions and, in the membranes, TatA-YFP fusion proteins formed in average 15 foci per cell that have been analyzed in detail and estimated to contain in average 25 copies of TatA (158). Foci occurred with no obvious preference for a polar localization but depended on TatC, and there was a pool of nonassembled TatA-YFP, suggesting that TatA-YFP has the ability to reversibly polymerize to large complexes (158).

In the case of minimal TatAC translocons, TatA has Tat $\mathrm{A}$ and TatB functionalities and TatB is absent (159). In these systems, TatC interacts with TatA, but TatA also forms independent complexes that are proposed to recruit Tat substrates to TatC $(156,157)$. In agreement with its bifunctional role, TatA of B. subtilis was found to be able to complement the phenotypes of $E$. coli $\Delta t a t A / E$ and $\Delta$ tatB mutant strains (135). In fact, sensitive assays showed that the E. coli Tat system can export low amounts of Tat substrates in the absence of TatB, indicating some residual TatAC translocation activity $(30,160)$. Interestingly, several single-site substitutions in TatA were sufficient to greatly improve the TatB functionality of TatA, thereby changing the E. coli system to a two-component TatAC system (160). In the absence of TatC, TatB assembles to a series of modular complexes as observed for TatA, underlining its TatA similarity (161). Therefore, at least in plants and proteobacteria, TatB can be regarded as a specialized TatA that has higher affinity to TatC, possibly facilitating the TatA/TatC interaction. TatC alone can form a $250-\mathrm{kDa}$ complex that is likely to serve as a scaffold for TatBC complex formation (161).

\section{Energetics and mechanism: membrane targeting and cooperation of the two Tat complexes}

The knowledge about this unusual protein transport pathway expanded rapidly in the early 1990s with many in vitro studies of the thylakoid system, in appreciation of the relatively 
simpler methods to prepare the thylakoid membrane vesicles and the high efficiency of this transport system (8-10). An increasing number of thylakoid lumenal proteins were found to be imported in a manner that is completely distinct from the well-known Sec pathway. This novel pathway required neither soluble protein factors on the cis side nor nucleoside triphosphates. Instead, a $\Delta \mathrm{pH}$ across the thylakoid membrane was found to drive protein import into the lumen, which is why this pathway was originally termed the ' $\Delta \mathrm{pH}$ pathway' $(9,162)$. Similar to that, transport of Tat substrates into E. coli inverted membrane vesicles was blocked upon dissipation of the proton motive force (pmf) $(163,164)$. However, the pmf is not required throughout the whole process since the recognition and targeting of precursor proteins to the Tat translocon could be achieved in the presence of uncouplers in vitro or in vivo $(165,166)$. In the absence of the pmf, precursors could bind to the TatBC complex inside the membrane; however, the translocation process was arrested at this state. In vitro Tat transport can be triggered by the electric potential $(\Delta \psi)$ component of the pmf $(167,168)$. It is possible that a pool of protons are kept away from the equilibrium by the translocon (169). About 80,000 protons have been calculated to pass the membrane for each protein translocated by the thylakoidal Tat system (170). It may be that this proton flow is not directly triggering translocation but rather reflecting a leakage that cannot be avoided during transport of fully folded proteins (20).

On the basis of the observed membrane interactions of several studies, it was postulated that in bacteria, as well as in plant plastids, a translocon-independent membrane interaction precedes recognition and translocation by the Tat system $(36,171)$. Later, this has been demonstrated in vitro for plants and more recently also for bacteria $(165,172)$. It thus could be that the initial targeting event of Tat substrates generally or in some cases - is a membrane insertion of the signal peptide. Signal peptides have been found to become protease protected upon Tat-independent membrane interaction. The length of the protease-protected region did not exceed the signal peptide in the case of the Tat substrate HiPIP (36), but included regions of the mature domain in case of a thylakoidal Tat substrate (173). The topology of the membrane-interacting $\mathrm{N}$-terminus of Tat substrates remains to be elucidated.

In three-component Tat systems such as in E. coli or plants, the first translocon interaction is believed to be the binding of the signal peptide to TatBC complexes (Figure 2B). TatC binds directly to the RR-motif of the signal peptides that can be deeply inserted into the lipid bilayer $(143,144)$. Interestingly, translocation of Tat substrates can proceed after covalent coupling of the RR-motif to TatC, indicating that bound Tat substrates do not need to be transferred completely to other complexes for translocation (144). The precise binding site of TatC has not been identified, but mutations in the twin-arginine motif could be compensated by point mutations, most of which mapped to the N-termini of TatB and TatC $(174,175)$. It seems that the entire N-terminal half of TatC is important for precursor recognition (130). A substrate-interacting TatBC complex has been visualized by electron microscopy (147). In photo cross-linking experiments, TatB was shown to bind not only to the signal peptide but also to the mature part of the precursor proteins, with the binding sites spanning the TMD, the hinge region, and the amphipathic helix of TatB (176). Site-directed mutagenesis failed to find any single essential residue in TatB (124), suggesting that the function of TatB depends on the context of multiple sites. TatBC complexes are oligomers and therefore contain multiple substrate-binding pockets that allow for a translocation of dimers or even tetramers at one time, which could be demonstrated in studies on the thylakoid Tat system (177).

After the specific binding of substrates by TatBC complexes, TatA joins the complex, possibly involving a rearrangement of TatA subunits, an assembly of tetramers to larger TatA complexes, or at least a significant change in TatA conformation $(145,178-180)$. The association of TatA with TatBC/Tat substrate complexes requires the pmf, which may be sensed by a conserved glutamate residue close to the lumenal side of the TMD in the case of the thylakoidal TatA that needs this residue to interact with TatBC/Tat substrate complexes (181). This negatively charged side chain is absent in $\gamma$-proteobacteria, albeit $E$. coli still shows a pmfdependent Tat complex association (145). The equivalent position is highly important for E. coli TatA (Q8) $(121,122)$, and may require polar residues. Direct interactions of TatA to Tat substrates have been found with the E. coli in vitro Tat system where a TatA-interacting intermediate accumulates possibly under translocon-overloading conditions (182). On the basis of a twin-arginine dependence of this TatA interaction, it is proposed that the TatA/Tat substrate complex is formed after a TatBC/Tat substrate binding event.

The exact role of TatA in the translocation is still unresolved. In Gram-positive bacteria, TatA has been implicated in a targeting to the TatC complex in the membrane (Figure 2D). Homooligomeric solubilized TatA complexes have been described that might represent gated TatA pores of variable size, implying a hand-over mechanism to a variable TatA pore in E. coli (152). Alternatively, Tat substrates may remain bound to TatC-containing complexes during transport and association of TatA could serve to permeabilize the membrane, which would permit a TatC-mediated pulling of the substrate through the membrane (171). This 'membraneweakening' model is supported by the observation that a covalently TatC-linked twin-arginine motif did not interfere with subsequent translocation of the globular Tat substrate (144). A recent structure of TatA from B. subtilis shows that the N-terminal TMD of TatA forms a hydrophobic helix that does not entirely span the membrane, and more flexible and less conserved residues near the $\mathrm{N}$-terminus reach to the membrane surface with several polar positions that may induce disorder, which would fit to a membrane-weakening model (119). Flexible TatA associations as observed with TatA-YFP fusions would be in agreement with both models (158). Further, there is no evidence that the oligomerization state of TatA after association with TatBC/Tat substrate complexes is influenced by the substrate size, which argues against the gated-pore model with pores that are fitted to the 
sizes of the substrates (180). However, since unfolded proteins of considerable length can be translocated by the Tat machineries of plants or bacteria, it is unlikely that a pulling event transfers substrates completely across the membrane $(66,68)$. Rather, it is likely that a pulling event only initiates translocation, such as by creating an opening that allows for a subsequent passage of the mature domain to the trans side of the membrane. This would also fit to energetic data that indicate a pmf requirement only at the initial stages of the translocation that can be followed by minutes of translocation completion without any further energy requirement (168).

The energetization of the transport thus requires the pmf (or its $\Delta \psi$ component) not only for the association of TatA to the translocon but most likely also for a later step of transport (168). It is unclear what exactly is driven by the pmf in this second step. It might be another subunit rearrangement or a conformational change (pulling or translocon-opening toward the trans side) of TatBC with the bound signal peptide.

\section{Aspects of structural high-resolution studies}

TatA complexes disassemble in detergent solutions, and solubilized TatA protomers can be structurally analyzed. A high-resolution nuclear magnetic resonance (NMR) structure of a TatA from B. subtilis $\left(\right.$ Tat $_{\mathrm{d}}$ - specifically involved in transport of the phosphatase PhoD) could be obtained that essentially showed that the predicted transmembrane helix, the hinge, and the amphipathic helix are indeed formed (119). The N-terminal TMD is rather short and not entirely helical in the solved structure (Figure 3). The short length and a tilt orientation of this TMD have also been noted in an NMR study (183). A stretch of about five residues at the $\mathrm{N}$-terminus of the TMD is of relatively lower hydrophobicity and does not necessarily participate in the helix formation (highlighted in brown in Figure 3D). We generated an alignment of a wide range of bacterial TatA sequences $(\alpha-, \beta-$, $\gamma-, \delta$-, and $\varepsilon$-proteobacteria; firmicutes; and actinobacteria) and found that this portion of the TMD generally is of lower hydrophobicity and less conserved than the helix-forming two-thirds of the TMD (Figure 3C). The last position of this stretch is usually a hydrophilic residue or a glycine $(G$ in the case of the solved structure, Q in E. coli TatA, $\mathrm{K}$ in E. coli TatE). The structure confirms that the strictly conserved $G$ in the FG hinge motif is highly important for the formation of the hinge between the two helices. The hinge angle seems to be stabilized by hydrophobic interactions of F14 and L18 in the TMD, and a PLxxLP motif in the vicinity of the hinge (119). However, this motif is not highly conserved (Figure 3C). The highly conserved F20 of the FG hinge motif does not directly contribute to the hinge formation, and we suggest that it most likely serves to position the hinge at the membrane surface (Figure 3A).

The amphipathic helix is known to be functionally highly important and it is of key interest to know how this helix is positioned relative to the membrane surface. Recent studies showed that the amphipathic helix requires negatively charged phospholipids for efficient membrane interaction (184). Another study addressed the orientation of the amphipathic helix at the membrane surface and came to the result that two slant orientations are possible (185). In the solved B. subtilis TatA structure, the amphipathic helix has a length of 25 residues and is longer than predicted, extending up to position S49. However, only the first part up to F40 of this amphipathic helix is stable and shows typical amphipathic character (119). In our alignment, we observed that F40 and K41 are highly conserved in bacteria. Only in many cyanobacteria and in plant TatA (without known exceptions), the $\mathrm{K} 41$ position is exchanged by a Q. The FK motif is similarly highly conserved as the FG motif of the hinge, and, to our knowledge, this extraordinarily high degree of conservation has not been noted thus far. The F of the FK motif in E. coli (F39) is an essential residue $(122,123)$. Only aromatic amino acids are tolerated at this position (125). In E. coli, the K of the FK motif has been mutated in combination with three other $\mathrm{K}$ residues and this TatA $3 \mathrm{~K}>\mathrm{Q}$ variant was inactive (123). However, an additional K24A mutation restored activity to some extent (123). Cysteine exchanges at several positions in the amphipathic helix have been found to inactivate the Tat system, among which was the $\mathrm{K}$ of the FK motif (122). The F of the FK motif marks the end of the rigid part of the amphipathic helix, as revealed by NMR (119). We noted that in the B. subtilis TatA structure of $\mathrm{Hu}$ et al., the FK motif is directed toward the membrane surface and F40 is likely to be important for the correct orientation of the amphipathic helix (Figure 3B). If the orientation of the amphipathic helix is correct, the $\mathrm{K}$ is the only positively charged residue in the amphipathic helix that is directed to the membrane surface and, considering its high degree of conservation, it is likely to play a very important role in the phospholipid contacts of the amphipathic helix. On the Cterminal side of the FK motif, the amphipathic helix is rather flexible and of different character than on the N-terminal side the FK motif (119). It therefore might well be that the helix was extended beyond K41 owing to detergent effects. The amphipathic helix is followed by a negatively charged region that is unlikely to contact the membrane surface. This negatively charged region has been shown to be functionally important (121). Possibly this highly charged C-terminal region can prevent an insertion of the amphipathic helix into the lipid bilayer and a flipping of the C-terminus toward the trans side of the membrane.

As the conserved FK motif is most likely important for the anchoring and positioning of the amphipathic helix at the membrane surface, we can speculate that such a positioning may be related to the functional cycle of TatA. This may be the reversible association with TatC-containing complexes in three-component Tat systems, or even the reversible interaction with the cytoplasmic membrane, such as postulated for B. subtilis Tat $\mathrm{A}_{\mathrm{d}}$ that appears to be able to direct the Tat substrate PhoD from the cytoplasm to TatC in the membranes $(156,157)$. It is now clear that the TMD of Tat $A_{d}$ is rather short $(\sim 23 \AA)$ and thus may be designed for reversible membrane integration. If then a population of Tat $\mathrm{A}_{d}$ exists 


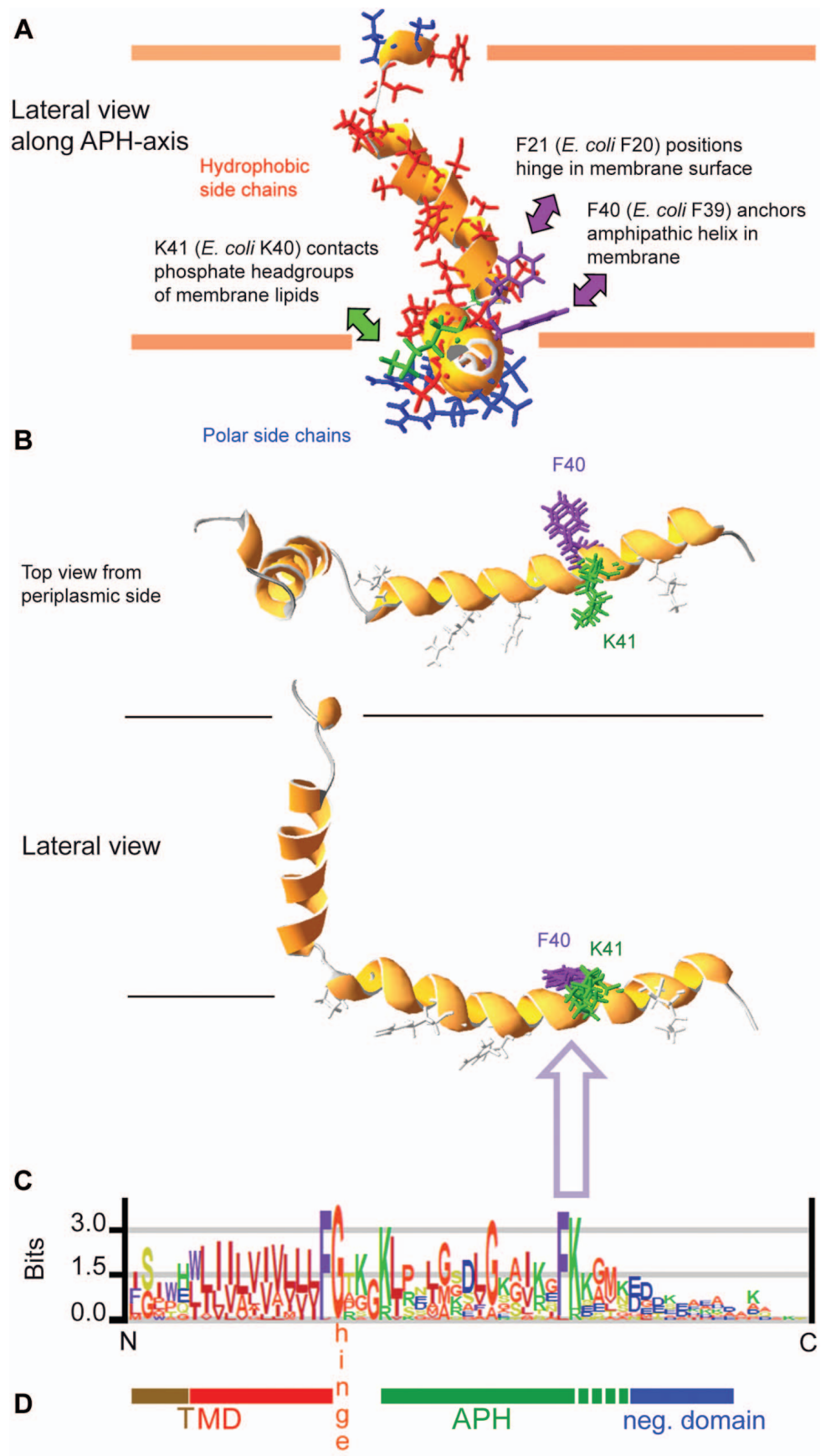

Figure 3 Implications based on the high-resolution structure of TatA.

(A-C) Structural model of B. subtilis Tat $_{\mathrm{d}}$ and its proposed positioning relative to the membrane. The view perspectives are described on the left and were generated using the PDB-file 2 L16 and the program SPDB-viewer (187). (A) Model including side chains of the TMD and the amphipathic helix, and their orientations relative to the membrane surface. The structure was oriented by positioning the amphipathic helix, which faces its polar side chains (blue) toward the aqueous phase and its hydrophobic side chains (red) toward the membrane, and the TMD, which shows a slightly tilted membrane-spanning orientation. The F of the FG motif in the hinge and both residues of the FK motif at the end of the amphipathic helix are highlighted ( $\mathrm{F}$ in purple, $\mathrm{K}$ in green). The $\mathrm{C}$-terminal region of the FK motif is removed for clarity reasons. (B) Models showing the positioning of the FK motif in the amphipathic helix. Note that the region of the amphipathic helix that follows the FK motif is more flexible and not predicted to be an amphipathic helix, and might not be formed in the absence of detergent. (C) Sequence logo of the functionally important N-terminal TatA region generated with the program enoLOGOS (188), based on 48 aligned TatA sequences from $\alpha-, \beta-, \gamma-, \delta$-, $\varepsilon$-proteobacteria; low-GC Gram-positive bacteria; and actinobacteria. (D) Schematic presentation of the TatA regions important for Tat transport. The N-terminal TMD is indicated in brown and red, with brown in the region of lower conservation and lower hydrophobicity and red in the region of the hydrophobic $\alpha$-helix. The amphipathic helix is indicated in green. Interruptions indicate the less conserved and less rigid region on the C-terminal side of the FK motif. The less conserved negative region is indicated in blue. 
as a soluble protein, how is the hydrophobic TMD shielded from the aqueous environment? It could be coincidental, but the length of the hydrophobic side of the amphipathic helix up to the FK motif matches the hydrophobic helical part of the TMD. Upon interaction with the negatively charged phospholipids and an initial contact of the tip of the stable amphipathic helix (the FK motif) with the membrane, the amphipathic helix may release the TMD into the membrane, thereby delivering the signal peptide to TatC, which would allow further translocation through the TatA environment (Figure 2D). Certainly, this is a speculation, but current models of TatA topology or TatA membrane interaction do not consider the possibility of reversible membrane interaction and cargo delivery function that has been proposed for Gram-positive bacteria, and this 'TatA docking and insertion model' is attractive, as it proposes for the first time a critical role of the amphipathic helix and its conserved FK motif in formation of soluble TatA populations and substrate targeting.

\section{Concluding remarks}

Organisms have developed multiple protein transport pathways to fulfill the demands of handling distinct types of proteins. Folded proteins can be translocated by the Tat pathway. To uncover the Tat mechanism means to reveal a new principle in biochemistry. Despite important advancements, the precise contributions of individual translocon components are still unclear, the structures of the corresponding Tat complexes are not solved at high resolution, and the transport mechanism and its energetization is under debate. The most fascinating questions thus remain to be answered and only hypothetical models exist that await being falsified or verified.

\section{Acknowledgments}

Support by the Deutsche Forschungsgemeinschaft (grant BR2285/ 1-3) is gratefully acknowledged.

\section{References}

1. Blobel G, Dobberstein B. Transfer of proteins across membranes. I. Presence of proteolytically processed and unprocessed nascent immunoglobulin light chains on membrane-bound ribosomes of murine myeloma. J Cell Biol 1975; 67: 835-51.

2. Pohlschröder M, Hartmann E, Hand NJ, Dilks K, Haddad A. Diversity and evolution of protein translocation. Annu Rev Microbiol 2005; 59: 91-111.

3. Müller M, Koch HG, Beck K, Schäfer U. Protein traffic in bacteria: multiple routes from the ribosome to and across the membrane. Prog Nucleic Acid Res Mol Biol 2001; 66: 107-57.

4. Prickril BC, Czechowski MH, Przybyla AE, Peck HD Jr, LeGall J. Putative signal peptide on the small subunit of the periplasmic hydrogenase from Desulfovibrio vulgaris. J Bacteriol 1986; 167: $722-5$.
5. van Dongen W, Hagen W, van den Berg W, Veeger C. Evidence for an unusual mechanism of membrane translocation of the periplasmic hydrogenase of Desulfovibrio vulgaris (Hildenborough), as derived from expression in Escherichia coli. FEMS Microbiol Lett 1988; 50: 5-9.

6. Rodrigue A, Chanal A, Beck K, Müller M, Wu LF. Co-translocation of a periplasmic enzyme complex by a hitchhiker mechanism through the bacterial Tat pathway. J Biol Chem 1999; 274: 13223-8.

7. Niviere V, Wong SL, Voordouw G. Site-directed mutagenesis of the hydrogenase signal peptide consensus box prevents export of a $\beta$-lactamase fusion protein. J Gen Microbiol 1992; 138: $2173-83$.

8. Klösgen RB, Brock IW, Herrmann RG, Robinson C. Proton gradient-driven import of the $16 \mathrm{kDa}$ oxygen-evolving complex protein as the full precursor protein by isolated thylakoids. Plant Mol Biol 1992; 18: 1031-4.

9. Cline K, Ettinger WF, Theg SM. Protein-specific energy requirements for protein transport across or into thylakoid membranes. Two lumenal proteins are transported in the absence of ATP. J Biol Chem 1992; 267: 2688-96.

10. Mould RM, Shackleton JB, Robinson C. Transport of proteins into chloroplasts. Requirements for the efficient import of two lumenal oxygen-evolving complex proteins into isolated thylakoids. J Biol Chem 1991; 266: 17286-9.

11. Chaddock AM, Mant A, Karnauchov I, Brink S, Herrmann RG, Klösgen RB, Robinson C. A new type of signal peptide: central role of a twin-arginine motif in transfer signals for the $\Delta \mathrm{pH}$ dependent thylakoidal protein translocase. EMBO J 1995; 14 : 2715-22.

12. Berks BC. A common export pathway for proteins binding complex redox cofactors? Mol Microbiol 1996; 22: 393-404.

13. Roffey RA, Theg SM. Analysis of the import of carboxyl-terminal truncations of the 23-kilodalton subunit of the oxygenevolving complex suggests that its structure is an important determinant for thylakoid transport. Plant Physiol 1996; 111: 1329-38.

14. Settles AM, Yonetani A, Baron A, Bush DR, Cline K, Martienssen R. Sec-independent protein translocation by the maize Hcf106 protein. Science 1997; 278: 1467-70.

15. Weiner JH, Bilous PT, Shaw GM, Lubitz SP, Frost L, Thomas GH, Cole JA, Turner RJ. A novel and ubiquitous system for membrane targeting and secretion of cofactor-containing proteins. Cell 1998; 93: 93-101.

16. Sargent F, Bogsch EG, Stanley NR, Wexler M, Robinson C, Berks BC, Palmer T. Overlapping functions of components of a bacterial Sec-independent protein export pathway. EMBO J 1998; 17: 3640-50.

17. Kipping M, Lilie H, Lindenstrauss U, Andreesen JR, Griesinger C, Carlomagno T, Brüser T. Structural studies on a twin-arginine signal sequence. FEBS Lett 2003; 550: 18-22.

18. Tullman-Ercek D, Delisa MP, Kawarasaki Y, Iranpour P, Ribnicky B, Palmer T, Georgiou G. Export pathway selectivity of Escherichia coli twin-arginine translocation signal peptides. J Biol Chem 2007; 282: 8309-16.

19. Berks BC, Palmer T, Sargent F. Protein targeting by the bacterial twin-arginine translocation (Tat) pathway. Curr Opin Microbiol 2005; 8: 174-81.

20. Natale P, Brüser T, Driessen AJ. Sec- and Tat-mediated protein secretion across the bacterial cytoplasmic membrane - distinct translocases and mechanisms. Biochim Biophys Acta 2008; 1778: $1735-56$.

21. Rose RW, Brüser T, Kissinger JC, Pohlschröder M. Adaptation of protein secretion to extremely high-salt conditions by exten- 
sive use of the twin-arginine translocation pathway. Mol Microbiol 2002; 45: 943-50.

22. Robinson C, Bolhuis A. Tat-dependent protein targeting in prokaryotes and chloroplasts. Biochim Biophys Acta 2004; 1694: 135-47.

23. Halbig D, Hou B, Freudl R, Sprenger GA, Klösgen RB. Bacterial proteins carrying twin- $\mathrm{R}$ signal peptides are specifically targeted by the $\Delta \mathrm{pH}$-dependent transport machinery of the thylakoid membrane system. FEBS Lett 1999; 447: 95-8.

24. Wexler M, Bogsch EG, Klösgen RB, Palmer T, Robinson C, Berks BC. Targeting signals for a bacterial Sec-independent export system direct plant thylakoid import by the $\Delta \mathrm{pH}$ pathway. FEBS Lett 1998; 431: 339-42.

25. Mori H, Cline K. A signal peptide that directs non-Sec transport in bacteria also directs efficient and exclusive transport on the thylakoid $\Delta \mathrm{pH}$ pathway. J Biol Chem 1998; 273: 11405-8.

26. Bendtsen JD, Nielsen H, Widdick D, Palmer T, Brunak S. Prediction of twin-arginine signal peptides. BMC Bioinformatics 2005; 6: 167.

27. Dilks K, Rose RW, Hartmann E, Pohlschröder M. Prokaryotic utilization of the twin-arginine translocation pathway: a genomic survey. J Bacteriol 2003; 185: 1478-83.

28. Halbig D, Wiegert T, Blaudeck N, Freudl R, Sprenger GA. The efficient export of NADP-containing glucose-fructose oxidoreductase to the periplasm of Zymomonas mobilis depends both on an intact twin-arginine motif in the signal peptide and on the generation of a structural export signal induced by cofactor binding. Eur J Biochem 1999; 263: 543-51.

29. Buchanan G, Sargent F, Berks BC, Palmer T. A genetic screen for suppressors of Escherichia coli Tat signal peptide mutations establishes a critical role for the second arginine within the twin-arginine motif. Arch Microbiol 2001; 177: 107-12.

30. Ize B, Gerard F, Zhang M, Chanal A, Voulhoux R, Palmer T, Filloux A, Wu LF. In vivo dissection of the Tat translocation pathway in Escherichia coli. J Mol Biol 2002; 317: 327-35.

31. Bachmann J, Bauer B, Zwicker K, Ludwig B, Anderka O. The Rieske protein from Paracoccus denitrificans is inserted into the cytoplasmic membrane by the twin-arginine translocase. FEBS J 2006; 273: 4817-30.

32. Molik S, Karnauchov I, Weidlich C, Herrmann RG, Klösgen RB. The Rieske Fe/S protein of the cytochrome b6/f complex in chloroplasts: missing link in the evolution of protein transport pathways in chloroplasts? J Biol Chem 2001; 276: 42761-6.

33. Hinsley AP, Stanley NR, Palmer T, Berks BC. A naturally occurring bacterial Tat signal peptide lacking one of the 'invariant' arginine residues of the consensus targeting motif. FEBS Lett 2001; 497: 45-9.

34. Ignatova Z, Hornle C, Nurk A, Kasche V. Unusual signal peptide directs penicillin amidase from Escherichia coli to the Tat translocation machinery. Biochem Biophys Res Commun 2002; 291: 146-9.

35. Stanley NR, Palmer T, Berks BC. The twin arginine consensus motif of Tat signal peptides is involved in Sec-independent protein targeting in Escherichia coli. J Biol Chem 2000; 275: 11591-6.

36. Brüser T, Yano T, Brune DC, Daldal F. Membrane targeting of a folded and cofactor-containing protein. Eur J Biochem 2003; 270: 1211-21.

37. Brink S, Bogsch EG, Edwards WR, Hynds PJ, Robinson C. Targeting of thylakoid proteins by the $\Delta \mathrm{pH}$-driven twin-arginine translocation pathway requires a specific signal in the hydrophobic domain in conjunction with the twin-arginine motif. FEBS Lett 1998; 434: 425-30.
38. Mendel S, McCarthy A, Barnett JP, Eijlander RT, Nenninger A, Kuipers OP, Robinson C. The Escherichia coli TatABC system and a Bacillus subtilis TatAC-type system recognise three distinct targeting determinants in twin-arginine signal peptides. J Mol Biol 2008; 375: 661-72.

39. Ize B, Gerard F, Wu LF. In vivo assessment of the Tat signal peptide specificity in Escherichia coli. Arch Microbiol 2002; 178: $548-53$.

40. Cristóbal S, de Gier JW, Nielsen H, von Heijne G. Competition between Sec- and TAT-dependent protein translocation in Escherichia coli. EMBO J 1999; 18: 2982-90.

41. Brüser T, Deutzmann R, Dahl C. Evidence against the doublearginine motif as the only determinant for protein translocation by a novel Sec-independent pathway in Escherichia coli. FEMS Microbiol Lett 1998; 164: 329-36.

42. Blaudeck N, Kreutzenbeck P, Freudl R, Sprenger GA. Genetic analysis of pathway specificity during posttranslational protein translocation across the Escherichia coli plasma membrane. J Bacteriol 2003; 185: 2811-9.

43. Bogsch E, Brink S, Robinson C. Pathway specificity for a $\Delta \mathrm{pH}-$ dependent precursor thylakoid lumen protein is governed by a 'Sec-avoidance' motif in the transfer peptide and a 'Sec-incompatible' mature protein. EMBO J 1997; 16: 3851-9.

44. Lüke I, Handford JI, Palmer T, Sargent F. Proteolytic processing of Escherichia coli twin-arginine signal peptides by LepB. Arch Microbiol 2009; 191: 919-25.

45. Frielingsdorf S, Klosgen RB. Prerequisites for terminal processing of thylakoidal Tat substrates. J Biol Chem 2007; 282: 24455-62.

46. Palmer T, Sargent F, Berks BC. Export of complex cofactorcontaining proteins by the bacterial Tat pathway. Trends Microbiol 2005; 13: 175-80.

47. Nurizzo D, Halbig D, Sprenger GA, Baker EN. Crystal structures of the precursor form of glucose-fructose oxidoreductase from Zymomonas mobilis and its complexes with bound ligands. Biochemistry 2001; 40: 13857-67.

48. John M, Schmitz RP, Westermann M, Richter W, Diekert G. Growth substrate dependent localization of tetrachloroethene reductive dehalogenase in Sulfurospirillum multivorans. Arch Microbiol 2006; 186: 99-106.

49. Sturm A, Schierhorn A, Lindenstrauss U, Lilie H, Brüser T. YcdB from Escherichia coli reveals a novel class of Tatdependently translocated hemoproteins. J Biol Chem 2006; 281: 13972-8.

50. Ize B, Stanley NR, Buchanan G, Palmer T. Role of the Escherichia coli Tat pathway in outer membrane integrity. Mol Microbiol 2003; 48: 1183-93.

51. Bernhardt TG, de Boer PA. The Escherichia coli amidase AmiC is a periplasmic septal ring component exported via the twinarginine transport pathway. Mol Microbiol 2003; 48: 1171-82.

52. Letoffe S, Heuck G, Delepelaire P, Lange N, Wandersman C. Bacteria capture iron from heme by keeping tetrapyrrol skeleton intact. Proc Natl Acad Sci USA 2009; 106: 11719-24.

53. Singh SK, Grass G, Rensing C, Montfort WR. Cuprous oxidase activity of cueO from Escherichia coli. J Bacteriol 2004; 186: 7815-7.

54. Tree JJ, Kidd SP, Jennings MP, McEwan AG. Copper sensitivity of cueO mutants of Escherichia coli K-12 and the biochemical suppression of this phenotype. Biochem Biophys Res Commun 2005; 328: 1205-10.

55. Widdick DA, Dilks K, Chandra G, Bottrill A, Naldrett M, Pohlschröder M, Palmer T. The twin-arginine translocation pathway is a major route of protein export in Streptomyces coelicolor. Proc Natl Acad Sci USA 2006; 103: 17927-32. 
56. Hutcheon GW, Bolhuis A. The archaeal twin-arginine translocation pathway. Biochem Soc Trans 2003; 31: 686-9.

57. Feilmeier BJ, Iseminger G, Schroeder D, Webber H, Phillips GJ. Green fluorescent protein functions as a reporter for protein localization in Escherichia coli. J Bacteriol 2000; 182: 4068-76.

58. Thomas JD, Daniel RA, Errington J, Robinson C. Export of active green fluorescent protein to the periplasm by the twinarginine translocase (Tat) pathway in Escherichia coli. Mol Microbiol 2001; 39: 47-53.

59. Santini CL, Bernadac A, Zhang M, Chanal A, Ize B, Blanco $\mathrm{C}$, Wu LF. Translocation of jellyfish green fluorescent protein via the Tat system of Escherichia coli and change of its periplasmic localization in response to osmotic up-shock. J Biol Chem 2001; 276: 8159-64.

60. Santini CL, Ize B, Chanal A, Müller M, Giordano G, Wu LF. A novel sec-independent periplasmic protein translocation pathway in Escherichia coli. EMBO J 1998; 17: 101-12.

61. Sanders C, Wethkamp N, Lill H. Transport of cytochrome c derivatives by the bacterial Tat protein translocation system. Mol Microbiol 2001; 41: 241-6.

62. DeLisa MP, Tullman D, Georgiou G. Folding quality control in the export of proteins by the bacterial twin-arginine translocation pathway. Proc Natl Acad Sci USA 2003; 100: 6115-20.

63. Clark SA, Theg SM. A folded protein can be transported across the chloroplast envelope and thylakoid membranes. Mol Biol Cell 1997; 8: 923-34.

64. Hynds PJ, Robinson D, Robinson C. The sec-independent twinarginine translocation system can transport both tightly folded and malfolded proteins across the thylakoid membrane. J Biol Chem 1998; 273: 34868-74.

65. Eilers M, Schatz G. Binding of a specific ligand inhibits import of a purified precursor protein into mitochondria. Nature 1986; 322: $228-32$

66. Cline K, McCaffery M. Evidence for a dynamic and transient pathway through the TAT protein transport machinery. EMBO J 2007; 26: 3039-49.

67. Richter S, Brüser T. Targeting of unfolded PhoA to the TAT translocon of Escherichia coli. J Biol Chem 2005; 280: 42723-30.

68. Richter S, Lindenstrauss U, Lücke C, Bayliss R, Brüser T. Functional Tat transport of unstructured, small, hydrophilic proteins. J Biol Chem 2007; 282: 33257-64.

69. Lindenstrauß U, Brüser T. Tat transport of linker-containing proteins in Escherichia coli. FEMS Microbiol Lett 2009; 295: 135-40.

70. Fan E, Jakob M, Klösgen RB. One signal is enough: stepwise transport of two distinct passenger proteins by the Tat pathway across the thylakoid membrane. Biochem Biophys Res Commun 2010; 398: 438-43.

71. Lindenstrauß U, Matos CF, Graubner W, Robinson C, Brüser T. Malfolded recombinant Tat substrates are Tat-independently degraded in Escherichia coli. FEBS Lett 2010; 584: 3644-8.

72. Fisher AC, Kim W, DeLisa MP. Genetic selection for protein solubility enabled by the folding quality control feature of the twin-arginine translocation pathway. Protein Sci 2006; 15: 449-58.

73. Fisher AC, DeLisa MP. Efficient isolation of soluble intracellular single-chain antibodies using the twin-arginine translocation machinery. J Mol Biol 2009; 385: 299-311.

74. Lim HK, Mansell TJ, Linderman SW, Fisher AC, Dyson MR, DeLisa MP. Mining mammalian genomes for folding competent proteins using Tat-dependent genetic selection in Escherichia coli. Protein Sci 2009; 18: 2537-49.
75. Fisher AC, Rocco MA, Delisa MP. Genetic selection of solubility-enhanced proteins using the twin-arginine translocation system. Methods Mol Biol 2011; 705: 53-67.

76. Dubini A, Sargent F. Assembly of Tat-dependent [NiFe] hydrogenases: identification of precursor-binding accessory proteins. FEBS Lett 2003; 549: 141-6.

77. Schubert T, Lenz O, Krause E, Volkmer R, Friedrich B. Chaperones specific for the membrane-bound [NiFe]-hydrogenase interact with the Tat signal peptide of the small subunit precursor in Ralstonia eutropha H16. Mol Microbiol 2007; 66: 453-67.

78. Hatzixanthis K, Palmer T, Sargent F. A subset of bacterial inner membrane proteins integrated by the twin-arginine translocase. Mol Microbiol 2003; 49: 1377-90.

79. Turner RJ, Papish AL, Sargent F. Sequence analysis of bacterial redox enzyme maturation proteins (REMPs). Can J Microbiol 2004; 50: 225-38.

80. Tranier S, Mortier-Barriere I, Ilbert M, Birck C, Iobbi-Nivol C, Mejean V, Samama JP. Characterization and multiple molecular forms of TorD from Shewanella massilia, the putative chaperone of the molybdoenzyme TorA. Protein Sci 2002; 11: $2148-57$

81. Ilbert M, Mejean V, Giudici-Orticoni MT, Samama JP, IobbiNivol C. Involvement of a mate chaperone (TorD) in the maturation pathway of molybdoenzyme TorA. J Biol Chem 2003; 278: 28787-92.

82. Ilbert M, Mejean V, Iobbi-Nivol C. Functional and structural analysis of members of the TorD family, a large chaperone family dedicated to molybdoproteins. Microbiology 2004; 150: 935-43.

83. Jack RL, Buchanan G, Dubini A, Hatzixanthis K, Palmer T, Sargent F. Coordinating assembly and export of complex bacterial proteins. EMBO J 2004; 23: 3962-72.

84. Genest O, Ilbert M, Mejean V, Iobbi-Nivol C. TorD, an essential chaperone for TorA molybdoenzyme maturation at high temperature. J Biol Chem 2005; 280: 15644-8.

85. Hatzixanthis K, Clarke TA, Oubrie A, Richardson DJ, Turner RJ, Sargent F. Signal peptide-chaperone interactions on the twin-arginine protein transport pathway. Proc Natl Acad Sci USA 2005; 102: 8460-5.

86. Li H, Chang L, Howell JM, Turner RJ. DmsD, a Tat system specific chaperone, interacts with other general chaperones and proteins involved in the molybdenum cofactor biosynthesis. Biochim Biophys Acta 2010; 1804: 1301-9.

87. Stevens CM, Winstone TM, Turner RJ, Paetzel M. Structural analysis of a monomeric form of the twin-arginine leader peptide binding chaperone Escherichia coli DmsD. J Mol Biol 2009; 389: 124-33.

88. Winstone TL, Workentine ML, Sarfo KJ, Binding AJ, Haslam $\mathrm{BD}$, Turner RJ. Physical nature of signal peptide binding to DmsD. Arch Biochem Biophys 2006; 455: 89-97.

89. Sarfo KJ, Winstone TL, Papish AL, Howell JM, Kadir H, Vogel HJ, Turner RJ. Folding forms of Escherichia coli DmsD, a twin-arginine leader binding protein. Biochem Biophys Res Commun 2004; 315: 397-403.

90. Ray N, Oates J, Turner RJ, Robinson C. DmsD is required for the biogenesis of DMSO reductase in Escherichia coli but not for the interaction of the DmsA signal peptide with the Tat apparatus. FEBS Lett 2003; 534: 156-60.

91. Oresnik IJ, Ladner CL, Turner RJ. Identification of a twin-arginine leader-binding protein. Mol Microbiol 2001; 40: 323-31.

92. Potter LC, Cole JA. Essential roles for the products of the $n a p A B C D$ genes, but not $n a p F G H$, in periplasmic nitrate reduc- 
tion by Escherichia coli K-12. Biochem J 1999; 344 Pt 1: 69-76.

93. Thomas G, Potter L, Cole JA. The periplasmic nitrate reductase from Escherichia coli: a heterodimeric molybdoprotein with a double-arginine signal sequence and an unusual leader peptide cleavage site. FEMS Microbiol Lett 1999; 174: 167-71.

94. Maillard J, Spronk CA, Buchanan G, Lyall V, Richardson DJ, Palmer T, Vuister GW, Sargent F. Structural diversity in twinarginine signal peptide-binding proteins. Proc Natl Acad Sci USA 2007; 104: 15641-6.

95. Mejean V, Iobbi-Nivol C, Lepelletier M, Giordano G, Chippaux M, Pascal MC. TMAO anaerobic respiration in Escherichia coli: involvement of the tor operon. Mol Microbiol 1994; 11: 1169-79.

96. Genest O, Neumann M, Seduk F, Stocklein W, Mejean V, Leimkuhler S, Iobbi-Nivol C. Dedicated metallochaperone connects apoenzyme and molybdenum cofactor biosynthesis components. J Biol Chem 2008; 283: 21433-40.

97. Genest O, Seduk F, Ilbert M, Mejean V, Iobbi-Nivol C. Signal peptide protection by specific chaperone. Biochem Biophys Res Commun 2006; 339: 991-5.

98. Li SY, Chang BY, Lin SC. Coexpression of TorD enhances the transport of GFP via the TAT pathway. J Biotechnol 2005; 122: 412-421.

99. Chanal A, Santini CL, Wu LF. Specific inhibition of the translocation of a subset of Escherichia coli TAT substrates by the TorA signal peptide. J Mol Biol 2003; 327: 563-70.

100. Bilous PT, Cole ST, Anderson WF, Weiner JH. Nucleotide sequence of the dms $A B C$ operon encoding the anaerobic dimethylsulphoxide reductase of Escherichia coli. Mol Microbiol 1988; 2: 785-95.

101. Weiner JH, Rothery RA, Sambasivarao D, Trieber CA. Molecular analysis of dimethylsulfoxide reductase: a complex iron - sulfur molybdoenzyme of Escherichia coli. Biochim Biophys Acta 1992; 1102: 1-18.

102. Chan CS, Winstone TM, Chang L, Stevens CM, Workentine ML, Li H, Wei Y, Ondrechen MJ, Paetzel M, Turner RJ. Identification of residues in DmsD for twin-arginine leader peptide binding, defined through random and bioinformatics-directed mutagenesis. Biochemistry 2008; 47: 2749-59.

103. Sambasivarao D, Turner RJ, Simala-Grant JL, Shaw G, Hu J, Weiner JH. Multiple roles for the twin arginine leader sequence of dimethyl sulfoxide reductase of Escherichia coli. J Biol Chem 2000; 275: 22526-31.

104. Chan CS, Howell JM, Workentine ML, Turner RJ. Twin-arginine translocase may have a role in the chaperone function of NarJ from Escherichia coli. Biochem Biophys Res Commun 2006; 343: 244-51.

105. Ize B, Coulthurst SJ, Hatzixanthis K, Caldelari I, Buchanan G, Barclay EC, Richardson DJ, Palmer T, Sargent F. Remnant signal peptides on non-exported enzymes: implications for the evolution of prokaryotic respiratory chains. Microbiology 2009; 155: 3992-4004.

106. Pérez-Rodríguez R, Fisher AC, Perlmutter JD, Hicks MG, Chanal A, Santini CL, Wu LF, Palmer T, DeLisa MP. An essential role for the DnaK molecular chaperone in stabilizing over-expressed substrate proteins of the bacterial twin-arginine translocation pathway. J Mol Biol 2007; 367: 715-30.

107. Graubner W, Schierhorn A, Brüser T. DnaK plays a pivotal role in Tat targeting of $\mathrm{CueO}$ and functions beside SlyD as a general Tat signal binding chaperone. J Biol Chem 2007; 282: 7116-24.
108. Weininger U, Haupt C, Schweimer K, Graubner W, Kovermann M, Brüser T, Scholz C, Schaarschmidt P, Zoldak G, Schmid FX, Balbach J. NMR solution structure of SlyD from Escherichia coli: spatial separation of prolyl isomerase and chaperone function. J Mol Biol 2009; 387: 295-305.

109. Holzapfel E, Moser M, Schiltz E, Ueda T, Betton JM, Müller M. Twin-arginine-dependent translocation of SufI in the absence of cytosolic helper proteins. Biochemistry 2009; 48: 5096-105.

110. Bernhardt TG, Roof WD, Young R. The Escherichia coli FKBP-type PPIase SlyD is required for the stabilization of the E lysis protein of bacteriophage $\phi X 174$. Mol Microbiol 2002; 45: 99-108.

111. Chung KC, Zamble DB. The Escherichia coli metal-binding chaperone SlyD interacts with the large subunit of [NiFe]hydrogenase 3. FEBS Lett 2011; 585: 291-4.

112. Kaluarachchi H, Sutherland DE, Young A, Pickering IJ, Stillman MJ, Zamble DB. The Ni(II)-binding properties of the metallochaperone SlyD. J Am Chem Soc 2009; 131: 18489-500.

113. Zhang JW, Butland G, Greenblatt JF, Emili A, Zamble DB. A role for SlyD in the Escherichia coli hydrogenase biosynthetic pathway. J Biol Chem 2005; 280: 4360-6.

114. Wexler M, Sargent F, Jack RL, Stanley NR, Bogsch EG, Robinson C, Berks BC, Palmer T. TatD is a cytoplasmic protein with DNase activity. No requirement for TatD family proteins in sec-independent protein export. J Biol Chem 2000; 275: $16717-22$.

115. Sargent F, Stanley NR, Berks BC, Palmer T. Sec-independent protein translocation in Escherichia coli. A distinct and pivotal role for the TatB protein. J Biol Chem 1999; 274: 36073-82.

116. Bogsch EG, Sargent F, Stanley NR, Berks BC, Robinson C, Palmer T. An essential component of a novel bacterial protein export system with homologues in plastids and mitochondria. J Biol Chem 1998; 273: 18003-6.

117. Yen MR, Tseng YH, Nguyen EH, Wu LF, Saier MH Jr. Sequence and phylogenetic analyses of the twin-arginine targeting (Tat) protein export system. Arch Microbiol 2002; 177: 441-50.

118. Porcelli I, de Leeuw E, Wallis R, van den Brink-van der Laan E, de Kruijff B, Wallace BA, Palmer T, Berks BC. Characterization and membrane assembly of the TatA component of the Escherichia coli twin-arginine protein transport system. Biochemistry 2002; 41: 13690-7.

119. Hu Y, Zhao E, Li H, Xia B, Jin C. Solution NMR Structure of the TatA Component of the twin-arginine protein transport system from gram-positive bacterium Bacillus subtilis. J Am Chem Soc 2010; 132: 15942-4.

120. Stevenson LG, Strisovsky K, Clemmer KM, Bhatt S, Freeman M, Rather PN. Rhomboid protease AarA mediates quorumsensing in Providencia stuartii by activating TatA of the twinarginine translocase. Proc Natl Acad Sci USA 2007; 104: 1003-8

121. Warren G, Oates J, Robinson C, Dixon AM. Contributions of the transmembrane domain and a key acidic motif to assembly and function of the TatA complex. J Mol Biol 2009; 388: 122-32.

122. Greene NP, Porcelli I, Buchanan G, Hicks MG, Schermann SM, Palmer T, Berks BC. Cysteine scanning mutagenesis and disulfide mapping studies of the TatA component of the bacterial twin arginine translocase. J Biol Chem 2007; 282: 23937-45.

123. Barrett CM, Robinson C. Evidence for interactions between domains of TatA and TatB from mutagenesis of the TatABC 
subunits of the twin-arginine translocase. FEBS J 2005; 272: 2261-75.

124. Maldonado B, Kneuper H, Buchanan G, Hatzixanthis K, Sargent F, Berks BC, Palmer T. Characterisation of the membrane-extrinsic domain of the TatB component of the twin arginine protein translocase. FEBS Lett 2011; 585: 478-84.

125. Hicks MG, Lee PA, Georgiou G, Berks BC, Palmer T. Positive selection for loss-of-function tat mutations identifies critical residues required for TatA activity. J Bacteriol 2005; 187: 2920-5.

126. Lee PA, Buchanan G, Stanley NR, Berks BC, Palmer T. Truncation analysis of TatA and TatB defines the minimal functional units required for protein translocation. $\mathrm{J}$ Bacteriol 2002; 184: 5871-9.

127. Ki JJ, Kawarasaki Y, Gam J, Harvey BR, Iverson BL, Georgiou G. A periplasmic fluorescent reporter protein and its application in high-throughput membrane protein topology analysis. J Mol Biol 2004; 341: 901-9.

128. Behrendt J, Standar K, Lindenstrauss U, Brüser T. Topological studies on the twin-arginine translocase component TatC. FEMS Microbiol Lett 2004; 234: 303-8.

129. Punginelli C, Maldonado B, Grahl S, Jack R, Alami M, Schroder J, Berks BC, Palmer T. Cysteine scanning mutagenesis and topological mapping of the Escherichia coli twin-arginine translocase TatC Component. J Bacteriol 2007; 189: 5482-94.

130. Holzapfel E, Eisner G, Alami M, Barrett CM, Buchanan G, Lüke I, Betton JM, Robinson C, Palmer T, Moser M, Müller $\mathrm{M}$. The entire N-terminal half of TatC is involved in twinarginine precursor binding. Biochemistry 2007; 46: 2892-8.

131. Mori H, Summer EJ, Cline K. Chloroplast TatC plays a direct role in thylakoid $\Delta \mathrm{pH}$-dependent protein transport. FEBS Lett 2001; 501: 65-8.

132. Jongbloed JD, Grieger U, Antelmann H, Hecker M, Nijland $\mathrm{R}$, Bron S, van Dijl JM. Two minimal Tat translocases in Bacillus. Mol Microbiol 2004; 54: 1319-25.

133. Pop O, Martin U, Abel C, Müller JP. The twin-arginine signal peptide of PhoD and the TatAd/Cd proteins of Bacillus subtilis form an autonomous Tat translocation system. J Biol Chem 2002; 277: 3268-73.

134. Lindenstrauß U, Brüser T. Conservation and variation between Rhodobacter capsulatus and Escherichia coli Tat systems. J Bacteriol 2006; 188: 7807-14.

135. Barnett JP, Eijlander RT, Kuipers OP, Robinson C. A minimal Tat system from a gram-positive organism: a bifunctional TatA subunit participates in discrete TatAC and TatA complexes. J Biol Chem 2008; 283: 2534-42.

136. Barnett JP, van der Ploeg R, Eijlander RT, Nenninger A, Mendel S, Rozeboom R, Kuipers OP, van Dijl JM, Robinson C. The twin-arginine translocation (Tat) systems from Bacillus subtilis display a conserved mode of complex organization and similar substrate recognition requirements. FEBS J 2009; 276: $232-43$.

137. Dilks K, Gimenez MI, Pohlschröder M. Genetic and biochemical analysis of the twin-arginine translocation pathway in halophilic archaea. J Bacteriol 2005; 187: 8104-13.

138. Thomas JR, Bolhuis A. The $t a t C$ gene cluster is essential for viability in halophilic archaea. FEMS Microbiol Lett 2006; 256: 44-9.

139. Oates J, Barrett CM, Barnett JP, Byrne KG, Bolhuis A, Robinson C. The Escherichia coli twin-arginine translocation apparatus incorporates a distinct form of Tat $\mathrm{ABC}$ complex, spectrum of modular TatA complexes and minor TatAB complex. J Mol Biol 2005; 346: 295-305.
140. Cline K, Mori H. Thylakoid $\Delta \mathrm{pH}$-dependent precursor proteins bind to a cpTatC-Hcf106 complex before Tha4-dependent transport. J Cell Biol 2001; 154: 719-29.

141. Bolhuis A, Mathers JE, Thomas JD, Barrett CM, Robinson C. TatB and TatC form a functional and structural unit of the twin-arginine translocase from Escherichia coli. J Biol Chem 2001; 276: 20213-9.

142. Maldonado B, Buchanan G, Müller M, Berks BC, Palmer T. Genetic evidence for a TatC dimer at the core of the Escherichia coli twin arginine (Tat) protein translocase. J Mol Microbiol Biotechnol 2011; 20: 168-75.

143. Gerard F, Cline K. The thylakoid proton gradient promotes an advanced stage of signal peptide binding deep within the Tat pathway receptor complex. J Biol Chem 2007; 282: 5263-72.

144. Gerard F, Cline K. Efficient twin arginine translocation (Tat) pathway transport of a precursor protein covalently anchored to its initial cpTatC binding site. J Biol Chem 2006; 281: 6130-5.

145. Alami M, Lüke I, Deitermann S, Eisner G, Koch HG, Brunner J, Müller M. Differential interactions between a twin-arginine signal peptide and its translocase in Escherichia coli. Mol Cell 2003; 12: 937-46.

146. McDevitt CA, Buchanan G, Sargent F, Palmer T, Berks BC. Subunit composition and in vivo substrate-binding characteristics of Escherichia coli Tat protein complexes expressed at native levels. FEBS J 2006; 273: 5656-68.

147. Tarry MJ, Schafer E, Chen SY, Buchanan G, Greene NP, Lea SM, Palmer T, Saibil HR, Berks BC. Structural analysis of substrate binding by the TatBC component of the twin-arginine protein transport system. Proc Natl Acad Sci USA 2009; 106: 13284-9.

148. Berthelmann F, Brüser T. Localization of the Tat translocon components in Escherichia coli. FEBS Lett 2004; 569: 82-8.

149. Meile JC, Wu LJ, Ehrlich SD, Errington J, Noirot P. Systematic localisation of proteins fused to the green fluorescent protein in Bacillus subtilis: identification of new proteins at the DNA replication factory. Proteomics 2006; 6: 2135-46.

150. Ridder AN, de Jong EJ, Jongbloed JD, Kuipers OP. Subcellular localization of TatAd of Bacillus subtilis depends on the presence of TatCd or TatCy. J Bacteriol 2009; 191: 4410-8.

151. Berthelmann F, Mehner D, Richter S, Lindenstrauß U, Lünsdorf $\mathrm{H}$, Hause $\mathrm{G}$, Brüser $\mathrm{T}$. Recombinant expression of tat $A B C$ and tat $A C$ results in the formation of interacting cytoplasmic TatA tubes in Escherichia coli. J Biol Chem 2008; 283: 25281-9.

152. Gohlke U, Pullan L, McDevitt CA, Porcelli I, de Leeuw E, Palmer T, Saibil HR, Berks BC. The TatA component of the twin-arginine protein transport system forms channel complexes of variable diameter. Proc Natl Acad Sci USA 2005; 102: 10482-6.

153. de Leeuw E, Porcelli I, Sargent F, Palmer T, Berks BC. Membrane interactions and self-association of the Tat A and TatB components of the twin-arginine translocation pathway. FEBS Lett 2001; 506: 143-8.

154. Frielingsdorf S, Jakob M, Klösgen RB. A stromal pool of TatA promotes Tat-dependent protein transport across the thylakoid membrane. J Biol Chem 2008; 283: 33838-45.

155. De Keersmaeker S, Van Mellaert L, Schaerlaekens K, Van Dessel W, Vrancken K, Lammertyn E, Anne J, Geukens N. Structural organization of the twin-arginine translocation system in Streptomyces lividans. FEBS Lett 2005; 579: 797-802.

156. Pop OI, Westermann M, Volkmer-Engert R, Schulz D, Lemke C, Schreiber S, Gerlach R, Wetzker R, Müller JP. Sequencespecific binding of prePhoD to soluble TatAd indicates pro- 
tein-mediated targeting of the Tat export in Bacillus subtilis. J Biol Chem 2003; 278: 38428-36.

157. Schreiber S, Stengel R, Westermann M, Volkmer-Engert R, Pop OI, Müller JP. Affinity of TatCd for TatAd elucidates its receptor function in the Bacillus subtilis Tat translocase system. J Biol Chem 2006; 281: 19977-84.

158. Leake MC, Greene NP, Godun RM, Granjon T, Buchanan G, Chen S, Berry RM, Palmer T, Berks BC. Variable stoichiometry of the TatA component of the twin-arginine protein transport system observed by in vivo single-molecule imaging. Proc Natl Acad Sci USA 2008; 105: 15376-81.

159. Jongbloed JD, van der Ploeg R, van Dijl JM. Bifunctional TatA subunits in minimal Tat protein translocases. Trends Microbiol 2006; 14: 2-4.

160. Blaudeck N, Kreutzenbeck P, Müller M, Sprenger GA, Freudl R. Isolation and characterization of bifunctional Escherichia coli TatA mutant proteins that allow efficient Tat-dependent protein translocation in the absence of TatB. J Biol Chem 2005; 280: 3426-32.

161. Behrendt J, Lindenstrauss U, Brüser T. The TatBC complex formation suppresses a modular TatB-multimerization in Escherichia coli. FEBS Lett 2007; 581: 4085-90.

162. Robinson C, Klösgen RB, Herrmann RG, Shackleton JB. Protein translocation across the thylakoid membrane - a tale of two mechanisms. FEBS Lett 1993; 325: 67-9.

163. Alami M, Trescher D, Wu LF, Müller M. Separate analysis of twin-arginine translocation (Tat)-specific membrane binding and translocation in Escherichia coli. J Biol Chem 2002; 277: 20499-503.

164. Yahr TL, Wickner WT. Functional reconstitution of bacterial Tat translocation in vitro. EMBO J 2001; 20: 2472-9.

165. Hou B, Frielingsdorf S, Klösgen RB. Unassisted membrane insertion as the initial step in $\Delta \mathrm{pH} /$ Tat-dependent protein transport. J Mol Biol 2006; 355: 957-67.

166. Di Cola A, Robinson C. Large-scale translocation reversal within the thylakoid Tat system in vivo. J Cell Biol 2005; 171: 281-9.

167. Braun NA, Davis AW, Theg SM. The chloroplast Tat pathway utilizes the transmembrane electric potential as an energy source. Biophys J 2007; 93: 1993-8.

168. Bageshwar UK, Musser SM. Two electrical potential-dependent steps are required for transport by the Escherichia coli Tat machinery. J Cell Biol 2007; 179: 87-99.

169. Braun NA, Theg SM. The chloroplast Tat pathway transports substrates in the dark. J Biol Chem 2008; 283: 8822-8.

170. Alder NN, Theg SM. Energetics of protein transport across biological membranes. a study of the thylakoid $\Delta \mathrm{pH}$-dependent/cpTat pathway. Cell 2003; 112: 231-42.

171. Brüser T, Sanders C. An alternative model of the twin arginine translocation system. Microbiol Res 2003; 158: 7-17.

172. Bageshwar UK, Whitaker N, Liang FC, Musser SM. Interconvertibility of lipid- and translocon-bound forms of the bacterial Tat precursor pre-SufI. Mol Microbiol 2009; 74: 209-26.

173. Schlesier R, Klösgen RB. Twin arginine translocation (Tat)dependent protein transport: the passenger protein participates in the initial membrane binding step. Biol Chem 2010; 391: 1411-7.
174. Kreutzenbeck P, Kröger C, Lausberg F, Blaudeck N, Sprenger GA, Freudl R. Escherichia coli twin arginine (Tat) mutant translocases possessing relaxed signal peptide recognition specificities. J Biol Chem 2007; 282: 7903-11.

175. Strauch EM, Georgiou G. Escherichia coli tatC mutations that suppress defective twin-arginine transporter signal peptides. J Mol Biol 2007; 374: 283-91.

176. Maurer C, Panahandeh S, Jungkamp AC, Moser M, Müller M. TatB functions as an oligomeric binding site for folded Tat precursor proteins. Mol Biol Cell 2010; 21: 4151-61.

177. Ma X, Cline K. Multiple precursor proteins bind individual Tat receptor complexes and are collectively transported. EMBO J 2010; 29: 1477-88.

178. Mori H, Cline K. A twin arginine signal peptide and the $\mathrm{pH}$ gradient trigger reversible assembly of the thylakoid $\Delta \mathrm{pH} /$ Tat translocase. J Cell Biol 2002; 157: 205-10.

179. Dabney-Smith C, Cline K. Clustering of C-terminal stromal domains of Tha4 homo-oligomers during translocation by the Tat protein transport system. Mol Biol Cell 2009; 20: 2060-9.

180. Dabney-Smith C, Mori H, Cline K. Oligomers of Tha4 organize at the thylakoid Tat translocase during protein transport. J Biol Chem 2006; 281: 5476-83.

181. Dabney-Smith C, Mori H, Cline K. Requirement of a Tha4conserved transmembrane glutamate in thylakoid Tat translocase assembly revealed by biochemical complementation. $\mathrm{J}$ Biol Chem 2003; 278: 43027-33.

182. Panahandeh S, Maurer C, Moser M, DeLisa MP, Müller M. Following the path of a twin-arginine precursor along the TatABC translocase of Escherichia coli. J Biol Chem 2008; 283: 33267-75.

183. Müller SD, De Angelis AA, Walther TH, Grage SL, Lange C, Opella SJ, Ulrich AS. Structural characterization of the pore forming protein TatAd of the twin-arginine translocase in membranes by solid-state 15N-NMR. Biochim Biophys Acta 2007; 1768: 3071-9.

184. Chan CS, Haney EF, Vogel HJ, Turner RJ. Towards understanding the Tat translocation mechanism through structural and biophysical studies of the amphipathic region of TatA from Escherichia coli. Biochim Biophys Acta 2011; 1808: 2289-96.

185. Walther TH, Grage SL, Roth N, Ulrich AS. Membrane alignment of the pore-forming component TatA(d) of the twinarginine translocase from Bacillus subtilis resolved by solid-state NMR spectroscopy. J Am Chem Soc 2010; 132: 15945-56.

186. Samaluru H, SaiSree L, Reddy M. Role of SufI (FtsP) in cell division of Escherichia coli: evidence for its involvement in stabilizing the assembly of the divisome. J Bacteriol 2007; 189: 8044-52.

187. Guex N, Peitsch MC. SWISS-MODEL and the Swiss-PdbViewer: an environment for comparative protein modeling. Electrophoresis 1997; 18: 2714-23.

188. Workman CT, Yin Y, Corcoran DL, Ideker T, Stormo GD, Benos PV. enoLOGOS: a versatile web tool for energy normalized sequence logos. Nucleic Acids Res 2005; 33: W389-92.

Received June 30, 2011; accepted August 5, 2011 


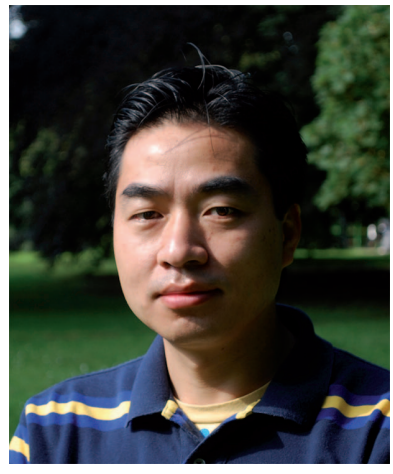

Bo Hou studied Molecular Biology at the Sichuan United University in Chengdu (China) and at the Shanghai Institute of Biochemistry, Chinese Academy of Science (Shanghai, China). He did his $\mathrm{PhD}$ in 2005 at the Institute of Plant Physiology of the University of Halle-Wittenberg (Germany), and then became Postdoc at the College of Medicine (Wehner-

Welch Research Lab) of the Texas A\&M University (USA). In 2011, he changed to the Institute of Microbiology at the Leibniz University Hannover (Germany), where he currently is building up his own group.

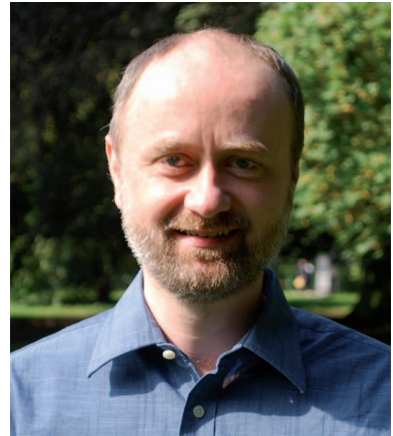

Thomas Brüser studied Biology with major Biochemistry at the Universities of Cologne (Germany) and Sussex (Brighton, UK). He received his $\mathrm{PhD}$ in Microbiology in 1999 at the University of Bonn (Germany), followed by a two-year Postdoc at the University of Pennsylvania (Philadelphia, USA). Thereafter, he became independent research group leader at the University of HalleWittenberg (Germany) and obtained his habilitation in Microbiology in 2006. Since 2009 he is full professor and head of the Institute of Microbiology at the Leibniz University Hannover (Germany). 